\title{
ISLEÑOS' SPANISH LANGUAGE PRESERVATION IN SAINT BERNARD PARISH: A CASE STUDY IN THE VOICES OF JOSEPH 'CHELITO’ CAMPO, IRVAN PEREZ AND ALLEN PEREZ
}

\author{
Fabiola Varela-García \\ University of Wisconsin-Eau Claire
}

\begin{abstract}
This qualitative case study examines Isleño Spanish language attrition and preservation in Saint Bernard Parish, New Orleans, when this linguistic variety was approaching extinction. It identifies levels of language maintenance in severely limited social communicative domains and studies language attitudes. The main aim is to compare Isleño Spanish with the 18th century Canary Spanish variety from which it originated. Using a panel study, the last of the Isleños speakers were followed over a fifty-year period analyzing their language in real time to report how the oldest and last fluent speakers had kept their Canary Island linguistic heritage. This dialectal research attests to extraordinary linguistic preservation in a handful of old speakers right before Hurricane Katrina forced the dismantling of the community in 2005.
\end{abstract}

KEYWORDS: Isleño Spanish, attrition, language loyalty, language maintenance, panel study

La conservación del español isleño en la parroquia de San Bernardo: un estudio longitudinal en las voces de Joseph ‘Chelito’ Campo, Irvan Perez y Allen Perez

RESUMEN: Este artículo examina la pérdida y conservación del español isleño en la parroquia de San Bernardo, en Nueva Orleans, cuando esta variedad estaba a punto de extinguirse. Identificaremos los niveles de mantenimiento lingüístico en situaciones comunicativas y sociales muy limitadas, así como las actitudes lingüísticas de los hablantes. El objetivo principal será comparar el español isleño con la variedad canaria del siglo XVIII en la que tuvo su origen. El enfoque longitudinal del que partimos permitirá seguir a los últimos hablantes de español isleño durante cincuenta años y analizar el uso de su idioma en tiempo real, para así comprobar cómo preservaron su herencia lingüística. Esta investigación dialectológica demuestra el grado extraordinario de conservación del español isleño entre los últimos hablantes, antes de que el huracán Katrina obligara al desmantelamiento de la comunidad en 2005.

PALABRAS CLAVE: español isleño, atrición lingüística, lealtad lingüística, mantenimiento lingüístico, estudio longitudinal 


\section{INTRODUCTION}

This is a historical dialectology case study which reports on unpublished data collected in the 1990 about a historical Spanish variety now extinct, Isleño Spanish, spoken in Louisiana from 1778 until 2005 when Hurricane Katrina devastated the area and the community was last dismantled. Isleño Spanish refers to the Spanish modality spoken by the descendants of the Canary Islanders who settled in the swampy area of Saint Bernard Parish in 1778 after France had ceded the state to Spain in 1763.

As Coles $(1999,5)$ states, a "combination of heritage, geographical isolation, and knowledge of dialect determines the boundaries of the Isleño speech community". While maintaining the features of 18th century Canary Islands' Spanish, the Isleño dialect incorporated elements from Cajun and Creole French, Caribbean Spanish, Portuguese, and English (MacCurdy, 1948, 1950; Lipski, 1990; Coles, 1991; Alvar, 1998; Lestrade, 2002; Samper and Hernández, 2009). Isleño Spanish (henceforth IS) survived the pressure of the English language over 200 years while the community was shifting from Spanish-only (17781920) to English-Spanish communal bilingualism. Language change accelerated during the last century when the community became bilingual, and by the 1990 s only a handful of Isleños were fluent in Spanish. By the time of my recordings in 1994-1998, no Isleño speaker was monolingual in Spanish, and few people spoke it fluently as L1. Traditional occupations and participation in dense social networks characterized these language keepers. Most (younger) fishermen affiliated to (different) social networks did not speak fluent Spanish. Because no new speakers had learned IS as L1 in the last 50 years, old age appeared to be the most important element in IS preservation. In the 1990s, English was already entering the most traditionally Spanish-speaking domains such as la décima's. ${ }^{1}$ Shrinking of communicative domains was alarming by the year 2000. Topics and events related to the past and local history triggered Spanish use if the listener was a Spanish speaker. But, even then, English was often used as everyone was bilingual.

In the face of such loss following Katrina, a study of the Isleños people has become even more important. Numerous studies have characterized IS as a unique, in attrition, vestigial variety (MacCurdy, 1948, 1950; Armistead, 1979, 1992; Lipski, 1984, 1985a, 1985b, 1987, 1990, 1993; Varela, 1986; Coles, 1991, 1999; Lestrade, 2002). However, while some researchers have emphasized the universal simplifying processes which IS allegedly shares with Creole languages (Lipski, 1985a, 1987), seldom do scholarly works claim IS to be a language variety whose original grammar, dating back to the Canary Islands, has been significantly preserved in the Isleño community (Alvar, 1998).

The purpose of this paper is twofold: to compare Isleño Spanish with the 18th century Canary Spanish variety from which it originated, and to describe the linguistic competence found in the last speakers of IS of Saint Bernard Parish. In the face of overwhelming research 
focusing on language shift towards English and treatment of IS as a dying language, the need for a complementary vision to document IS grammar preservation becomes essential as, indeed, the last speakers were old. This study aims to contribute to future discussions on L1 attrition by exploring functional preservation of a historic language variety and its grammar in an extreme adverse social situation. Resisting the pressure to fully assimilate to the English American culture, a handful of old bilingual speakers manifesting strong language loyalty kept their L1 communicatively while the language was socially approaching extinction.

\section{THEORETICAL FRAMEWORK}

It has been claimed that language disuse will lead to both structural and social reduction (Dorian, 1973, 1977; Andersen, 1982; Köpke, 2007; Paradis, 2007; Schmid, 2007). This has been often reported for IS, a variety with just a few speakers whose domains of use and areas of language (phonetics, morphology, syntax, and lexicon) have been described as in attrition.

Due to lack of intergenerational transmission, written norm, and support from administrative policies, deficiencies in communication strategies and grammar competence are expected. Yet, given that all IS speakers in this study were over 50 years of age, significant grammar loss and linguistic change were not anticipated. Sociolinguistics does not ponder age simply as demographic data but, rather, considers the ways in which social transformations affect the speech of adult speakers. Moreover, unless the minority group in a bilingual speech community loses its group status - which is not this case-, the group will create situations in which to use the group language for communicative purposes (Fishman, 1972). Furthermore, in multilingual settings, interlanguage shift happens for communication purposes, but, in daily communication, the shift to the ethnic language of the minority is not prompted by the need to functionally communicate, but rather by the intention to do so in a particular way. Once the intragroup norms are established, and if the minority group has speakers, they will continue using their language if the norm does not change. If the social structure changes, it will affect and change the language choice of the minority group and their norms (Fase, Jaspaert and Kroon, 1992, 6-7).

All IS speakers interviewed are language attriters (Andersen, 1982), that is, linguistically competent speakers who were more competent in Isleño Spanish in the past than now due to lack of use. There are gradations between a linguistically competent speaker and a language attriter, so it is crucial to limit the many dimensions of the linguistic features which are relevant for a language attriter. Accordingly, we will undertake a language use perspective: our focus will be on the description of the phonology, morphology, syntax, and lexicon. Rarely, any IS speaker reported full reading and writing competence, so we will describe their oral comprehension and production by cohort group and, occasionally, by individual speaker.

Andersen (1982, 85) distinguishes between dysfunctional and cosmetic attrition. Dysfunctional attrition implies loss of linguistic competence that deteriorates the 
communication; the language becomes "stigmatized", provoking "negative evaluation and attitudes" in the linguistically competent speakers and promoting "feelings of insecurity" and L1 rejection. Cosmetic attrition, which characterizes IS speakers in this study, refers to feature loss which neither interferes with communication nor provokes negative feelings towards the L1.

Linguistic reduction in dying languages is usually expected as consequence of loss of speakers, but an individual speaker in a language near extinction - such as IS- might speak an unreduced form of such variety. As Dorian (1977) claims, the fact that dying languages lose speakers does not mean that the ones who continue speaking their L1 are always semispeakers; many remain fluent in their L1. This loss can be restricted to a small number of uses, domains and frequency (Dorian, 1977, 24-30). A bilingual community might abandon an L1 of lesser prestige for a dominant language of economic and social advancement (Weinreich, 1963, 79), but convergence and reduction in form may be a functional adjustment to facilitate switching from one language to another for daily communication purposes while still maintaining two separate systems (Gumperz and Wilson, 1971). IS is undoubtedly a case of a community changing pattern of use over time, but this does not imply a total break with the continuous language use tradition (Andersen, 1982, 91). Therefore, we must identify which linguistic and attitudinal features are maintained and lost.

A speaker's amount of lexicon might depend on linguistic experience. As the oldest generation becomes the patrimonial language's repository, younger generations report loss of vocabulary (Dorian, 1973, 414). Bilingual speakers retrieving vocabulary in either language depends on the Activation Threshold (AT). The Activation Threshold refers to the frequency of use and the last time of activation (Paradis, 1993, 2004). It has been claimed that lack of vocabulary use will eventually affect the ability to access grammar, leading to gradual language loss with most commonly used L2 items replacing their less used L1 counterparts (Paradis, 2004; Köpke, 2007). Social situations such as different L1 used by the speaker's partner appear to correlate with subjects' more frequent L1 errors (Schmid, 2007, 136-137). Likewise, amount of contact with the primary network correlates strongly with accuracy and speed of L1 tasks (Hulsen, de Bot and Weltens, 2002).

A different approach is the bilingual language mode which considers potential attriters' language activation in a continuum: when both languages are regularly active, language mixing, codeswitching and interferences are recurrent (Schmid, 2007, 137-151). However, selection of the language mode happens through the two processes that determine the Activation Threshold: activation and inhibition so that speakers activating their L1 more often and recently will attrite less in this language. Likewise, L1 speakers communicating in L2 monolingual situations must inhibit all competing forms and languages which would make accessing the L1 more difficult. This frequency and recency activation and inhibition would impact language attrition (Paradis, 2004). 
IS falls into bilingual mode types III-IV-V in which L1 is used with family, friends, and acquaintances (type III) and L2 is used with monolingual speakers or with those with a rudimentary knowledge of L1 (types IV-V). In type III, little effort is expected to inhibit either L1 or L2 given the fact that choosing the L1 or the L2, mixing them or codeswitching are socially acceptable and communicatively appropriate. L1 attrition should not be significant. However, modes IV (L2 is used with native speakers with rudimentary knowledge of L1) and V (L2 is used with monolingual speakers and bilingual speakers of other languages) will require frequent use of L2 and L1 inhibition which will likely accelerate L1 attrition by impairment in lexical naming and fluency and hesitation (pauses, filled pauses, repetitions and self-repair) in free speech (Schmid, 2007, 137-142).

Even though this model has proven to correlate AT with L1 attrition, Schmid's $(2007,150)$ study on language modes - frequency and recency of L1 activation- claims no correlation between language use and L1 attrition. This conclusion makes her suggest a point of stabilization of knowledge through extensive rehearsal of the L1 until adulthood as stated by the Critical Period Hypothesis, thus suggesting a stronger effect of L1 inhibition on attrition due to the demands to L2 use in monolingual L2 contexts than to quantity of L1 use. Most models of linguistic behavior accept the Critical Period Hypothesis by which people's language remains stable from late adolescence or early childhood (Lenneberg, 1967). In variationist sociolinguistic studies, the Critical Period is crucial to the use of the present to explain the past and assumed in panel and trend research: "Panel studies provide a clear overall result: as they age, people register lesser differences from their earlier selves than does the community over the same time interval, as measured by a trend study" (Sankoff, 2006, 115). In Sankoff's own words, "our present synchronic methodology is a powerful lens for interpreting the past" (2006, 115).

\section{Purpose AND Limitations OF THIS STUdy}

By the time I conducted community fieldwork in 1994-1998, only a handful of bilingual speakers were able to communicate regularly using Isleño Spanish. This unique group had retained adequate linguistic competence to allow fluent communication among us and across linguistic norms. Documenting the degree of language preservation and loss in this near-extinction variety left disparate data and its analysis in a non-quantitatively fashion presents important methodological challenges. The very nature of this study with just three fluent speakers - less than ten in the community - limits its scope and methodology because gathered data and linguistic variation are insufficient to conduct quantitative analysis. But describing levels of language preservation and loss implies a comparative perspective. One analytical approach to overcome this limitation is to conduct a diachronic study to describe Canary Islands Spanish (CIS, henceforth) at the time it was brought to the United States and 
the language maintained by their descendants 200 years later. This was only possible when contrasting written CIS records with IS oral recordings of the 2oth century.

In addition to this approach, when studying language change, sociolinguists carefully examine how social processes affect the speech of adult speakers and design, accordingly, methodologies to consider language change at times of significant community transformation. Social and economic upheavals endured by the Isleños in the last century -hurricanes, WWI and WWII, end of isolation with road construction, the advent of telephone network and the school system - caused changes to the social fabric, altering Saint Bernard's ecosystem and ways of life for good. In the last decades of the 2oth century, the Louisiana government executed a development plan aiming to transform Saint Bernard into a boat resort for wealthy tourists. To accomplish their city planning goal, they changed the $\mathrm{pH}$ of water, making it difficult for the fishing boats to reach out to the Gulf. Nearby oil plants hired the men - especially the young ones- turning them from fishermen, trappers and farmers into industry workers.

All scholars doing linguistic fieldwork in the 2oth century in Saint Bernard (the first visits by MacCurdy in the 1940 s were followed by those of Armistead, Alvar, Lipski, Coles, Varela, Lestrade, and Varela-García in the 1970s, 1980s, 1990s and 2000) echoed the Isleños' concerns on the severe impact that those socioeconomic events had on the Isleños' culture and language, accelerating language shift towards English and IS loss. To attest to IS maintenance and loss, a methodology was needed to describe it at discreet points in time and according to community transformation-benchmarks.

Another important limitation is that none of the previous studies report their findings quantitatively or by individual speaker, but they all mention having worked with Joseph 'Chelito' Campo, Irvan Perez, and Allen Perez. I interviewed them all, so although I could not compare individual speakers across time, I still could design my research as a panel study on a cohort group and follow the same speakers over a 50-year span at a decade interval. In addition to this, I could report on their language as a group while presenting some language examples by individual speakers.

\section{Methodology AND RESEARCH DESIGN}

Fase, Jaspaert and Kroon $(1992,8)$ argue that language shift is related to the group, whereas language loss relates to the individual. Panel and trend sociolinguistic studies focus on speech of individuals and cohort groups recorded at different points in time using the present to explain the past (Labov, 1963; Sankoff, 2006, 2018). Labov's Martha Vineyard's seminal study (1963) showed that synchronic information can help reconstruct the history of language change and describe the regular nature of the speech community. To explain diphthong centralization in four age groups, he consulted older records in the Linguistic Atlas 
of New England which allowed him to compare the older speakers in 1933 and his speakers in 1961. Labov concluded the centralization he found was an age-grading change in apparent time.

Although following just one age group across time, this cohort study adheres to Labov's sociolinguistics tradition. The purpose is to describe the degree of language maintenance among fluent speakers of IS who were exclusively the oldest generation. Conversely, in order to identify any language loss, we needed to design a panel study and travel from the present to the past following the linguistic life of the same speakers across 50 years to describe language change in real time. The best way to report findings in a systematic way and overcome the complexity of comparing written and oral information previously accounted for in a qualitative fashion is detailing presence or absence of linguistic features. This is needed also because earlier studies throughout the 2oth century reported on the same speakers lumping their speech productions together as one group.

The goal of this panel study is twofold. First, I will compare the Spanish variety from which IS originated, 18th century Canary Spanish, with the dialect kept by its descendants 227 years later in its last stage. This approach will permit the identification of shared grammar, lost features, and new creative linguistic innovations over 200 years. And, second, I will describe IS loss and maintenance in its last 50 years of life, from 1940 to 2000.

My hypothesis will presuppose communicative language maintenance in a small group of fluent speakers, but I will also expect signs of language attrition. I argue that in bilingual community settings and in balanced bilinguals in which historical minority L1 is approaching death, functional group preservation of the L1 linguistic system at the near-native speaker level might occur even in the face of significant community shift to L2 and social domain shrinkage. To prove or refute this hypothesis, the following research questions were designed: a) which L1 internal or linguistic features (vocalic and consonantal inventories, morphological and syntactic systems, lexicon) and functions did the last speakers maintain and use when IS was approaching community extinction, when the dialect was compared, on the one hand, with the dialect of origin, and, on the other hand, with the language of the same speakers in the last 50 years?, and b) were positive ethnolinguistic attitudes (loyalty, prestige, status) about the L1 recognized and reported among the last speakers?

Fieldwork was conducted in Saint Bernard Parish in the summers of 1994, 1995, 1996, and 1998 when I recorded sociolinguistic interviews using the well-known Labovian methodology and traditional conversational modules (Labov, 1984; Poplack, 1979). In my first visit to Saint Bernard Parish, I contacted Irvan Perez, who introduced me to Joseph 'Chelito' Campo, his cousin Allen M. Perez, and many other Isleños with various levels of Spanish language competency. I classified them as fluent bilinguals, semi-speakers and rememberers (Coles, 1999, 5-8). During my first visits to the community, questionnaires were handed out to gather information about speakers' ancestry, age, schooling, profession, bilingual linguistic competency, and attitudes. In ensuing visits, sociolinguistic interviews among Isleños who were fluent in Spanish were conducted (Labov, 1984; Poplack, 1979). They were audio recorded 
during informal individual and group conversations. Film sessions captured Isleños' stories, décimas, proverbs and songs. I visited them in their houses, at their workplaces, and attended social gatherings such as décima events and the Isleños' Museum celebrations. I even accompanied them fishing in the Gulf of Mexico and was honored to be invited to a Louisiana State Department event where they publicly recognized Joseph 'Chelito' Campo's contribution to the Isleños' heritage preservation. At that event, Irvan Perez presented his 10-year old grandson as a decimero, passing the torch to his next in-line male descendant. ${ }^{2}$

Despite generalized language loss in the community, the elders showed remarkable language competency, as Lipski (1985a, 969) noted: "there are still a number of speakers of fluent, if somewhat Anglicized, Spanish in this group”. Yet, not enough attention has been given to the preservation of IS grammar in the oldest bilingual speakers who learned both languages as children before the age of 8.3 During my visits in Saint Bernard Parish, I assessed the community linguistic situation and interviewed 24 speakers: 4 the majority were monolingual English speakers, two were classified as rememberers, and six had near-native competency in IS. In addition to this, two speakers were of recent immigration from Valencia, Spain, and therefore their Spanish variety was not the local one. Of the six remaining fluent speakers, three were selected as subjects of this study because they had served, among others who had already passed, as linguistic subjects in seminal linguistic studies since the 1940s. This fact would allow me to build a panel study and assess language maintenance and change studying the same speakers in real time over a fifty-year course (table 1):5

\begin{tabular}{|l|c|c|c|}
\hline Age by decade & Allen Perez & Irvan Perez & Joseph 'Chelito' Campo \\
\hline $1940 \mathrm{~S}$ & $20 \mathrm{mid}$ & $20 \mathrm{~s}$ late & 5 Os \\
\hline $1970 \mathrm{~s}$ & $50 \mathrm{~s}$ & $50 \mathrm{~s}$ & $80 \mathrm{~s}$ \\
\hline $1980 \mathrm{~s}$ & $60 \mathrm{~s}$ & $60 \mathrm{~s}$ & $90 \mathrm{~s}$ \\
\hline $1990 \mathrm{~s}$ & $70 \mathrm{~s}$ & $70 \mathrm{~s}$ & $100 \mathrm{~s}$ \\
\hline
\end{tabular}

Table 1 . Speakers' age by decade

This paper, thus, describes IS language as the oldest speakers used it and analyzes the grammar of Irvan Perez, Allen Perez, and Joseph 'Chelito' Campo, three bilingual speakers ranging in ages from 75 to 102, who had learned Spanish — and English - as children, ${ }^{6}$ and who used it on a daily basis to communicate with other community members and in performative situations in décima festivals. ${ }^{7}$ Lack of significantly quantifiable sociolinguistic and stylistic variation in IS at its final stage and just a handful of fluent speakers did not call for a variationist quantitative methodology. Additionally, management of my information proved to be challenging due to the situation of some of the recordings. ${ }^{8}$ For this reason, data 
analysis is being presented in a qualitative fashion, only documenting presence or absence of a given phenomenon and whether it appears sporadically or regularly in the selected speakers. 9

I will report firstly on IS evolution, comparing synchronic information on fluent speakers with data from Canary Islands language dating back to the 18th century. Then, description and comparison between CIS's and IS's tonic and atonic vocalic inventories, consonantal system, morphology, syntax, and lexicon will permit the identification of the systematic, abstract, descriptive and normative rules shared at both points in time by this speech community. Methods of data collection include written documents (18th century letters and journals) from the Canary Islands, sociolinguistic oral interviews (1994-1998), décimas (both oral and written), and linguistic data in academic publications using phonetic annotations and morphological, syntactical, and lexicon analysis. Limitations of this case study in which a local historical L1 is preserved in adverse conditions will neither allow to establish cause-effect, nor interactions, nor probabilities, but to describe, compare, and reveal shared features proper of language maintenance, to identify lost elements across time as in language reduction, and to detect new changes pointing at linguistic innovations.

\section{18TH CENTURY CANARY ISLAND SPANISH BROUGHT TO LOUISIANA}

The scholarly work describing 18th century Canary Islands' Spanish is not abundant. The islands were colonized by Castile between 1402 and 1496. The Spanish spoken by the first colonizers was a conservative, meridional Andalusian variety with Portuguese elements. Today, Canary Spanish shares features with southern dialects in Spain and in Latin America: it is seseante, although remnants of ceceo exist in rural Tenerife; people still aspirate Latin ' $\mathrm{f}$ ', and $/ \mathrm{x} /$; and yeísmo is the norm today. Palatal lateral $/ K /$ and an occlusive $/ \mathrm{t} \int /$ were brought to the islands with the conquest; yet, these features today are only documented in older speakers in El Hierro. Confusion between liquids / $\mathrm{f}$ / and /l/ was and still is common among sailors. There is word-internal /s/ aspiration, deletion, and assimilation. Additionally, words from Guanche, Galician, Portuguese, and Caribbean Spanish made their way into the Canary variety (Lapesa, 1965, 333-334).

Leísmo is not documented early on but personal leísmo is common today. In her study of 18th century Canary Islands Spanish, Díaz Alayón (2005) reports etymological uses of la/las, lo/los as direct objects and le/les as indirect in the letters that Silvestre Izquierdo, a middleman from Tenerife, wrote between 1769-1786 to his landowner. Conversely, she also finds cases of laísmo and personal leísmo in the works of writers José de Viera y Clavijo and José Agustín Álvarez Rixo. ${ }^{10}$ Rarely, but still present, are loísmo examples in Álvarez Rixo's manuscripts. These uses are not found in familiar and social contexts.

Medina López (1997) and Morera (2004) analyze 18th century Canary Islands Spanish based on immigrants' and travelers' letters, testamentary documents, literary texts, and 
education treaties. They illustrate instability in the atonic vocalic system and describe dissimilation and assimilation, diphthongization of hiatus /ae/ /ea/ /eo/ /oa/, and the conversion of hiatus in diphthongs. Epenthetic yod, yod elision, and protheses /g/+ vowel /u/ are also documented (Morera, 2004, 158-161). The variability of the unstressed vocalic system brought to Louisiana survived in Saint Bernard. All five processes were attested in fluent speakers of Isleño Spanish in my sample: istilo, legarta, dispues, lantejas, pion, cambear, desucupar, fondiados, entriegue, creeendo, guevo, and guerta, among other examples. However, they are not exclusively pronunciations of IS but, rather, generalized features proper of rural, archaic Spanish in Spain and Latin America.

Regarding consonantal features of 18th century Canary Islanders' speech, and according to Morera (2004), in the letters of Silvestre Izquierdo and the diary of trader Antonio Betancourt there is no trace of yeísmo, while in the journal of politician and lawyer Isidoro Romero Ceballos both spellings are confused, an indication of his yeísmo (vallamos 'vayamos', olleron 'oyeron', desarroyaron 'desarrollaron', calló 'cayó', lleguas 'yeguas'). As noted by Morera (2004, 170): “Obviamente no se trata de una práctica de pronunciación general en el archipiélago por la época que nos ocupa, sino simplemente de un hecho idiolectal, que afecta solamente al hablante que consideramos, que, como sabemos, había nacido y vivido los primeros nueve años de su vida en Caracas”. Medina López $(1997,179)$ also states that confusion between $/ K /$ and $/ \mathrm{j} /$ resulting in yeísmo was not documented from the $16^{\text {th }}$ through the 18th centuries in the Canary Islands, although it appears to be frequent in Andalusia (Corrales and Corbella, 2004, 88).

None of IS speakers practiced $/ \kappa-/ y /$ alternation, but rather yeísmo. However, cases of Isleño Spanish writing distinction in the performative style of the décimas were found. Usually, these traditional songs were written by the decimeros at the request of researchers. The three decimero speakers of this sample learned to write English at school or were self-taught. Irvan Perez reported he could read Spanish un poco, 'a little', feeling more comfortable reading and writing in English. Most of the décimas reflect loss of $/ \Lambda-/ \mathrm{y} /$ distinction in favor of yeísmo: los yeva y los trai 'los lleva y los trae', yegó el temporal 'llegó el temporal'. But, we also find cuando llegamos 'cuando llegamos', me llevaron 'me llevaron', Juanillo 'Juanillo', y halla 'halla'. The lateral palatal phoneme exists, at least in Isleño speakers' linguistic awareness. Although they do not pronounce it, they write it in the more formal décima style despite their limited Spanish literacy.

Although seseo appears in written documents in the Canary Islands since mid- $15^{\text {th }}$ century, Viera y Clavijo describes it as a "defect", expressing his concern for the vacillations and aberrations of spelling of scribes (Corrales and Corbella, 2004, 79-81). Morera (2004, 162) reports frequent seseo (resibi 'recibí', disen 'dicen', pucieron 'pusieron') and Medina López (1997, 182) attests to seseo and generalized sibilant spelling confusion in alveolars and dentialveolars: conosco 'conozco', asucar/açucares 'azucar', ofisio 'oficio', confieza 'confiesa', 
pacion 'pasión'. Other consonantal features are sporadic voicing of /p/, /t/, and /k/ next to liquid, as in alguiladas 'alquiladas' (Morera, 2004, 166-167), although Medina López (1997, 185) claims that this process is already completed by the 18 th century. Morera $(2004,167,169)$ also reports deletion of intervocalic [ð] (mi entaura 'mi dentadura'), word final loss of /n/ and also reinsertion in existential naiden, as well as maintenance or loss of Latin consonantal groups: perfesion 'perfección', narahas 'naranjas', alquerir 'adquirir', aseten 'acepten' are found in these early documents. Other features are consonantal metathesis (frabiqué 'fabriqué') (Morera 2004, 173), $d / r$ neutralization (voluntar 'voluntad') and liquids metathesis (perlado 'prelado', adrento 'adentro', presonas 'personas' (Medina López, 1997, 179). Latin 'f' appears frequently aspirated (joyo 'hoyo', jase 'hacer'), although Medina López $(1997,185)$ also documents initial Latin $-f$ in XVII century texts. Aspiration of Castilian /x/ (hunta 'junta') and aspiration and deletion of syllable final /s/ (juntah 'juntas', díah 'días') are documented as well (Morera 2004, 164).

Regarding the nominal and verbal morphology and some syntactic features attested in 18th century Canary Islands Spanish, Morera (2004) and Medina López (1997) comment on the use of the diminutive and its social class distribution. Thus, -ito is employed to show affection and is found in higher social classes, as occurs in Nicolasito. It is also used to express time and location: tardecita, ahorita. The diminutives -ico, -illo are used with mitigating meaning, such as in Aniquita (Morera 2004, 174-178). Regarding subject pronominal use in the Canary Islands (Medina López, 1996, 19), Juan de la Puerta Canseco in 1854 attests usted, usía and vuecencia as urban forms coexisting with ustedes. Sufix -ero and -ada are attested (pimenteras, dilubiada). Other characteristics, pointed by Morera (2004, 180-184), include verbal aphaeresis (marran 'amarran') and verbs with prefix a- (ajuntava 'juntaban'); periphrasis with 'pegar' meaning 'empezar' ('begin'), like in tengo yntension de pegar aderesar las pipas 'tengo intención de empezar a aderezar las pipas', and preference to use the preterit tense over the present perfect. Morera also documents imperfect subjunctive in -ra and -se (llegara, avisase) and imperfect future subjunctive (biniere 'viniere'). Analogical forms such as quedrá 'querrá' and archaic and new prepositional forms (en el día 'por el día', barlobentiando con la noche 'barloventear por la noche') are also found in 18th century Spanish in the Canary Islands along with word order sequences such as paresiome muy granado 'me pareció', mandárame pescado 'me mandara pescado,' and postposition of possessive pronoun as in de la casa mía 'de mi casa' (Morera, 2004, 184-185).

Linguistic 18th century CIS features found and absent in 2oth century IS are listed below. Symbols (+) and (-) mean the feature is present or absent; (+ -) means the feature was present in CIS and absent in IS; and (?) means inconclusive. If only one symbol appears it applies to both 18th century and IS today.

1. Vocalic system: yod elision (+); instability of unstressed vocalic system: a) assimilation and dissimilation (+); b) hiatus diphthongization (+), epenthetic yod (+). 
2. Consonantal system:

2.1. Atlantic Spanish features: predorsal dental /s/ (+); aspiration and deletion of /s/, /x/, final /-d/ and /-n/ (+); /r/ /l/ neutralization (+); intervocalic -d- deletion (+).

2.2. Other features: сесеo CIS (+) / IS (?); hypercorrection $/ \mathrm{g}+\mathrm{u} /=>$ [bu] (+); CIS yeísmo (+) and distinction (+) / IS yeísmo (+); aspiration of Latin ' $\mathrm{f}$ ' (+).

3. Morphology and syntax: differences in pronominal treatment $(+/-)$; leísmo (+/-); cual, cuala, cualo (-/+) (cf. MacCurdy, Coles); verbal aphaeresis (+); verbal periphrasis with 'pegar' $(+)$; word order: de la casa mía (+), paresiome muy granado (+/-).

All these features, with the exception of ceceo, yeísmo/lleísmo distinction, and (some) wordorder cases, are commonly found in other varieties of Spanish today besides IS.

\section{A PANEL STUDY: LANGUAGE MAINTENANCE AND LOSS IN REAL TIME: ISLEÑO SPANISH FROM} THE 1940 S TO 2000.

Before proceeding with this panel study and analyzing the linguistic system of the cohort group, this paper will discuss a few social (age, gender, domain of language use, listener, topic of conversation, occupation, network participation) and attitudinal (identity, local status, décima, loyalty) factors that appear to be relevant in L1 attrition. Among the first, age was a factor of language maintenance in this community. All fluent speakers, both males and females, were in their 70 s and beyond at the time of data collection. Likewise, although the prominent role that men played in language and cultural preservation through décima composition and singing is irrefutable, the fluent women in IS in Saint Bernard Parish were able to carry out conversations at the same near-native level as the men. Gender, then, did not appear to be a determinant influence in L1 maintenance.

One of the factors frequently linked to language attrition refers to domain of uses. In language attrition situations, it has been claimed that the home is the last domain of use being lost (Schmidt's mode III). However, this is not always the case. Irvan Perez, one of the most active leaders in Isleño language and culture preservation during the last fifty years, did not speak Spanish at home simply because his wife Louise was of Italian descent and did not speak Spanish. Irvan did not pass Spanish down to their four daughters, who were all monolingual English speakers. He spoke his L1 when there were other Spanish speakers around, even if his conversation partners used a different modern norm. This proves, first, that same L1 language of the listener is a condition for L1 use, although it did not trigger L1 categorical use in bilingual settings where L1 and L2 could and were interchanged. Second, intergroup marriage will present challenges for L1 maintenance. Thirdly, as it is widely known, intergenerational L1 transmission is key in language maintenance. 
An important question arises at this point: if every Isleño-fluent Spanish speaker in this community was also fluent in English, what factors triggered language choice? The Isleños were interviewed at meetings and association gatherings which were conducted in English. The only domain free of English competition was the performative space of décima singing. But lately, even English was making its way into those occasions, and even Irvan Perez would sing the décima "The Father's Prayer" both in English and Spanish. As he explained, décima singing was transmitted patrilineally, so he was teaching his grandson Nicola, 10 years old in 1998. Nicola could not speak Spanish at all, but, in the face of language death, Irvan Perez was fully aware of the importance of transmitting community values through the décima. Although he composed Spanish décimas in order to pass down Isleños' values, such as the family reputation and good name, Irvan understood he had to compose his final décimas also in English. ${ }^{11}$

Certain topics of conversation related to customs, old stories, riddles, local history, and life events from childhood and adolescence appeared to trigger Spanish over English. Local and traditional occupations such as fishing, trapping, and farming also seemed to have favored L1 use. MacCurdy (1950), Armistead (1981) and Alvar (1998) collected testimonies of families and groups of men spending weeks at a time in the marshlands and at sea, trapping, farming, and fishing. These occupations had favored families' and small groups of men's participation in dense and tight networks while living in relative isolation for weeks at a time during which they spoke only Spanish.

Isleño speakers had a strong sense of local identity and intra-group loyalty, and enjoyed undeniable community status and prestige. They were also Isleño culture and language advocates, having been recognized by the US State Department and by the Smithsonian Museum as well as visited by former King and Queen of Spain and Prime Minister Adolfo Suárez among other authorities. The Canary Islands Government had also invited and honored them. They were undoubtedly committed to preserving and promoting their culture. Despite the language domain's significant shrinking, this linguistic attitude and loyalty might help explain the remarkable maintenance among this handful of last speakers and partially account for the similarities between the Spanish linguistic system that arrived from the Canary Islands and 2oth century Spanish in Saint Bernard.

Even so, did the L1 of this group experience reduction in the last fifty years? At this point, it is central to examine the language of these speakers in real time comparing the evolution of IS throughout the 1940s-1950s, 1970s-1980s, and 1990s, including the data I collected up to the late 1990s.

The information in this section is organized by linguistic components. I first illustrate the IS's phonology (atonic and tonic vocalic and consonantal systems), followed by a description of IS nominal and verbal morphology. Then, I give an account of the syntactic features that characterize IS with some attention to language contact between Spanish and English. Every section presents tables containing data analysis conducted at different points in time by seminal linguistic researchers. Every table portrays IS as reported by MacCurdy (1948) in the 
1940s-1950s, followed by Armistead (1981, 1992), Varela (1986) and Alvar (1998), ${ }^{12}$ in the 1970s-1980s. Next, I present Lipski’s (1985a, 1985b, 1987, 1990, 1993), Coles' (1999) and Lestrade's $(1999,2002)$ linguistic analysis completed in the 1990s. Finally, I include my own results on each table and current Canary Islands Spanish.

Every table presents data in a binary mode. The symbols (+) (-) signify the presence or absence of a given phonetic, morphological, or syntactic phenomenon as reported by each researcher. An empty cell means no information was found or reported.

\subsection{Phonology}

\subsubsection{Vocalic system}

Table 2 displays vocalic features at different points in time:

\begin{tabular}{|c|c|c|c|c|c|}
\hline Phenomenon & $\begin{array}{l}\text { 1940s } \\
\text { MacCurdy }\end{array}$ & $\begin{array}{l}\text { 1970s-1980s } \\
\text { Armistead, Varela, } \\
\text { Alvar }\end{array}$ & $\begin{array}{l}\text { 1990s } \\
\text { Lipski, Coles, } \\
\text { Lestrade }\end{array}$ & $\begin{array}{l}\text { 1994-1998 } \\
\text { Varela-García }\end{array}$ & 2oth c. CIS \\
\hline $\begin{array}{l}\text { Instability of } \\
\text { unstressed } \\
\text { vowels }\end{array}$ & + & $\begin{array}{l}+ \text { Armistead } \\
(\text { seldom } o>u \text {, } \\
e>o \text { ) } \\
+ \text { Alvar (in general; } \\
\text { sporadically } o>u \text { ) }\end{array}$ & $\begin{array}{l}\text { Systematic ón }> \\
\tilde{o} n, u \\
\text { + Lipski } \\
\text { + Coles } \\
\text { + Lestrade }\end{array}$ & $\begin{array}{l}\text { + sporadically }(o> \\
u \text { ) } \\
\text { Systematic ón }> \\
\tilde{o} n, u\end{array}$ & $\begin{array}{l}\text { + (all after }-n \text { loss) } \\
\text { - Almeida (exception } \\
\text { vs. rule) }\end{array}$ \\
\hline $\begin{array}{l}\text { Lengthening } \\
\text { stressed vowels }\end{array}$ & & + Alvar & + Coles & + also unstressed & $\begin{array}{l}\text { + Alvar } \\
\text { - Almeida }\end{array}$ \\
\hline $\begin{array}{l}\text { Vocalic openness } \\
\text { after } / s \text { / } \\
\text { aspiration and } \\
\text { deletion }\end{array}$ & + & $\begin{array}{l}\text { + Armistead } \\
+ \text { Alvar }\end{array}$ & + Coles & + & + \\
\hline $\begin{array}{l}\text { Conversion of } \\
\text { hiatus into } \\
\text { diphthongs }\end{array}$ & $\begin{array}{l}+ \\
\text { diphthong } \\
\text { reduction }\end{array}$ & + Alvar & & + & + \\
\hline $\begin{array}{l}\text { Hiatus } \\
\text { preservation }\end{array}$ & + & + & & + & + \\
\hline $\begin{array}{l}\text { Diphthongs } \\
\text { become hiatus }\end{array}$ & + & + & & + & + \\
\hline Epenthetic yod & + & + & & + & + \\
\hline Yod loss & + & + & & + & + \\
\hline Aphaeresis & + & + & & + & + \\
\hline $\begin{array}{l}\text { Vocalic apocope } \\
\text { /syncope }\end{array}$ & -+ & + & & + & + \\
\hline $\begin{array}{l}\text { Reduction } \\
\text { unstressed /e/ } \\
\text { /o/ /a/ to /Ә/ }\end{array}$ & & & $\begin{array}{l}\text { + Lipski } \\
\text { + Coles } \\
\text { + Lestrade }\end{array}$ & $\begin{array}{l}\text { Sporadically and } \\
\text { borrowings }\end{array}$ & \\
\hline
\end{tabular}

Table 2. Isleño Spanish vocalic system 


\subsubsection{Tonic vowels}

As reported by MacCurdy (1950, 27), IS tonic vocalic system is still quite stable. Even today, bilingual speakers maintain archaisms: 'truxe 'traje' 'I brought', mesmo 'mismo' 'the same', semos 'somos' 'we are'. These vocalic archaic forms coexist in free variation in my sample with the standard forms 'mismo', 'traje', and 'somos'. Data results are reported in this section immediately after the legend CC, IP, AP, which stand for Joseph 'Chelito' Campo, Irvan Perez, and Allen Perez. All examples that appear next to these annotations ([CC], [IP], [AP]) from section 6.1.1.2 until section 6.1.1.4 are my data.

Stressed vowel [u] is stable ([no 'luhko laiðða] no luzco la edad 'I don't represent my age' [CC]), and [i] is laxed even when it is tonic: [ ' Jisen] $y$ dicen 'and they say' [CC]. Usually stressed vowels do not exhibit instability; this finding might be due to English influence. Contrary to MacCurdy (1950) and Alvar (1998), I neither documented tonic $e>i$ nor ón $>[u]$, but ón $>\tilde{o n}$ with a certain degree of vocalic closure that never resulted in [u].

\subsubsection{Atonic vowels}

Overall instability of unstressed vowels has been widely documented in MacCurdy (1950), Armistead (1981, 1992), Alvar (1998), and Coles (1999). As in Coles (1999), the speakers of this sample articulate laxed [e] [i] in closed syllables preceding aspirated and deleted /s/; also, in open syllables:

(1) ['saßch] sabes 'you know' [CC] [IP]

(2) [nuch 'frio, $\varepsilon$ ?hun do 'lore] no es frío, es un dolor 'it's not the cold, it's a pain' [CC]

(3) [eh lo ke $\varepsilon:]$ es lo que es 'it is what it is' [CC]

Unstressed vowel [e] often experiments vowel raising regardless of its distribution:

(1) [I 'ð Isen ke no 'luhko larðða] y dicen que no luzco la edad 'and they say I don't represent my age' $[\mathrm{CC}]$

(2) [ah si' yuro] ah seguro 'ah for sure!'[CC]

But $[\mathrm{e}]$ is also pronounced as a lax reduced centralized vowel:

(1) [nombre en əhpanひł] nombre en español 'name in Spanish' [CC]

(2) [ene ləh 'tomayo] en el estómago 'in the stomach' [CC]

Like Coles (1999), I found [ə] in unstressed syllables in borrowings, but while she documented it in semi-speakers under 50, I identified this outcome in bilinguals over 70 : 
(1) [treylə] treila 'trailer'

(2) [trolə] trole, troles 'trawl' [IP, AP]

Vocalic lengthening is also attested:

(1) ['eja e: \# la ef 'pofa ðe jo' nito] Ella es \# la esposa de Johnito' 'She is Jonny's wife' [CC]

Likewise, vowels [a], [o] are, at times, unstable constrained by /s/ with the following results:

1) Vowel [a] opening and raising: ['tengo 'nõmbre de toạ ma' neræ] tengo nombre de todas maneras 'I have a name in all ways (languages)' [CC].

2) Vowel [o] is laxed: ['no' sotrə 'seməh 'komə el tiempo] nosotros somos como el tiempo 'we are like the weather' $[\mathrm{CC}]$. Or it is a mid-rounded tense vowel: [mu' ffisimo 'saño] muchísimos años 'many years' [CC]. Lax [o] also occurs in open syllable: ['komə el tiempo] como el tiempo 'like the weather'.

As in MacCurdy (1950, 27), ${ }^{13}$ I documented aphaeresis of initial $a$ : ([prendieron] 'aprendieron', [yuantßan] 'aguantaban' [IP, CC]), and generalized vowel instability:

(1) $a>$ e: legarto 'lagarto' [IP, AP].

(2) $e>a$ in initial syllable constrained by [r]: harmoso 'hermoso', harmano 'hermano' $[\mathrm{IP}, \mathrm{AP}]$.

(3) $e>i$ by assimilation: disir 'decir', pidir 'pedir'; when it is followed by a tonic diphthong containing an [i]: confisión 'confesión'; and in some words, such as tinimos 'tenemos' (MacCurdy, 1950, 28), disi 'dice', disimo 'decimos' [CC]. Also, by dissimilation: pelia 'pelear' [IP].

(4) $i>e$ : [kambea] 'cambia' [IP], [ofisena] 'oficina' [IP], [mehmo] 'mismo' [IP] [CC] [AP].

(5) o > a: atorgar 'otorgar' (MacCurdy, 1950, 28), [malero] 'Molero' [IP].

(6) $o>$ e: estión 'ostión' [CC, IP].

(7) o > u: by assimilation: cubertura 'cobertura'; verbal forms in the preterit: uyí 'oí', uyeron 'oyeron', durmí 'dormí' [CC, IP].

(8) Vowel lowering is common as in $u>0$ : resocitar 'resucitar' [IP, AP].

The same instability is found in post-tonic vowels, often in word final position: $e>a$ : menaja 'menaje' (MacCurdy, 1950, 28), [irena] 'Irene' [CC]. I did not document $e>i$ after 
voiceless consonant, specifically [t] nochi 'noche', lechi 'leche', but, as in MacCurdy (1950, 29), muchu 'mucho', ríu 'río' were documented. I found instances of $o>$ u fríu ‘frío' [CC].

\subsubsection{Diphthongs}

Regarding behavior of tonic [a, e, o] in diphthongs, and as described in MacCurdy (1950, 29-30), the following pronunciations were still present-day:

(1) ai maintenance: both maintenance and lax, reduced [i], as in jaiba, jaba, were still pronounced [IP, AP].

(2) au reduced to [a] or [u]: anque, unque 'aunque' [CC, IP, AP].

(3) ai < ei: asaite 'aceite', ray 'rey', but reina and peine [CC, IP, AP].

(4) iu < eu: diuda 'deuda', but romatismo 'reumatismo' [CC, IP].

(5) $e<$ ie: pacensia 'paciencia' [CC, IP, AP].

(6) ea < ia: cambeamiento 'cambiamiento' [CC, IP, AP].

(7) Metathesis: [naide] 'nadie' [CC, IP, AP], common in rural Spanish and in US heritage speakers.

(8) a < ia: lupa 'lupia' [CC, IP].

(9) ua: when intervocalic -d- is deleted in the -uda ending, vowel [a] is deleted as well 'peluda' pelú (MacCurdy, 1975, 46) [CC, IP, AP].

(10) ue from Latin coexists with 'o' in forms as pos 'pues', logo 'luego', po, podo 'puedo' $[\mathrm{CC}, \mathrm{IP}, \mathrm{AP}]$.

Coles $(1999,16)$ reported on IS's diphthongs overall stability.

\subsubsection{Hiatus}

A glottal stop between adjacent vowels is still found in Isleño Spanish, as documented by MacCurdy (1950, 30) and Armistead (1979). Armistead noted this phenomenon notably reduced: 'que el' > que?el, [CC, IP, AP]. As noted by MacCurdy (1950, 30), similar adjacent vowels within a word are reduced to one vowel without timber change ('leer' > ler, 'creer' > crer [CC, IP]) and after intervocalic -d-dropping: 'nada' > na, 'todo' > to [CC, IP].

Contrary to MacCurdy (1950, 30) and Alvar (1998, 41), who documented mái and máiz, I attested hiatus [aí] in 'maíz'. Other features documented by MacCurdy (1950, 1975) are:

(1) Raising of [e] in diphthong áe to [i]: 'cae' > cai [CC, IP]. Despite [aé] is frequently kept, at times it changes to ái, or to e: cáir or quer [CC, IP]. 
(2) MacCurdy (1950, 30) documented 'ahora' > ahóra, áhora and áura. I only documented ahóra, áhora [CC, IP]. The sequence áo remains stable: 'bacalao' > bacalao.

(3) Attested eá > iá ('real' > rial, 'teatro' > tiatro) (MacCurdy, 1975, 517) is still found today in Saint Bernard; also, reduction to [a] in pelaban 'peleaban' [CC, IP, AP].

(4) eó > ió: 'peor' > piór [CC, IP, AP].

(5) eí > i: 'sonreír' > sonrir; old forms 'veía' > vía and 'creía' > cría are kept [CC, IP].

(6) oá > uá: 'toalla' > tualla [CC, IP].

(7) oí > uí as in uído 'oído' [IP, AP, CC].

(8) ía > hiatus as in 'había' > habiá, 'tenía' > teniá [IP].

(9) io > is kept: 'río', 'frío'; it coexists with [íu] 'fríu'.

(10) uí, a yod is inserted in between the two vowels: 'huír' > juyir [IP, AP].

The unstressed system appears to be still quite unstable with vowels / a e o/ being raised, then lowered after having lost the Spanish-like tension and elongated. These realizations coexist in free variation with standard Spanish vowel pronunciation in all positions. Today's Isleños' unstressed vowel system is like MacCurdy's in 1950, a system documented across the rural Spanish-speaking world. Some vocalic laxing might be due to recent English influence. Opposite to MacCurdy (1948) and much like Coles (1999), I found change of [e] to [i] when it is followed by diphthong [ue], as in dispués. Like in MacCurdy, the speakers in my sample raised at times final unstressed vowels [o] to [ou], and raised [e] to [i] by assimilation (disir 'decir') and dissimilation (peliar 'pelear').

Examples of vocalic prosthesis (abajar 'bajar', arregar 'regar'), epenthetic yod and yod loss, aphaeresis, and vocalic apocope and syncope were also collected. Reduction of unstressed /e/ /o/ /a/ to /ə/ occurs but less frequently than in Coles' reports. Finally, Alvar (1998) and Coles (1999) also reported on lengthening of stressed vowels as in English, but speakers in this research study infrequently did so.

\subsubsection{Consonantal system}

Except for lleísmo, the system is very similar to 18th century CIS and shares features with present southern Spanish and Caribbean varieties. Liquids' variation -lambdacism, rhoticism, aspiration, deletion, gemination and even /l/ vocalization-, like in Caribbean Spanish, would prompt some to claim IS inherited these features from Caribbean dialects. However, these phenomena are historically found in Andalusian and Canary Spanish.

Most linguists concur when it comes to define the IS consonantal system, although there are some disagreements. Alvar (1998) speaks of a post dental ce as in ceceo and of a strong palatal ch coexisting with an adherent realization of lesser distribution in IS. Only a very palatal 
ch was documented in this research, but some ciceante pronunciation in the oldest speakers was detected. However, the main point of contention refers to the presence or absence of velar $-n$ in word and phrase end. Lipski $(1985 \mathrm{~b}, 1987,1990)$ and Coles (1999) consider lack of velar $-n$ as the most defining trait of IS. Like MacCurdy $(1948,1950)$ and Alvar (1998), I reported a velar $-n$ in these environments. MacCurdy (1948, 1950) and Alvar (1998) also claimed vocalization of word final /l/ and /er/ before consonant and while every linguist reported on /r/ metathesis, only Alvar (1998) considers / r/ metathesis the unique feature in IS. MacCurdy (1948, 1950) reported extremely rare / $\mathrm{f} /$ word final lateralization.

Table 3 displays the description of consonants in IS in the last fifty years:

\begin{tabular}{|c|c|c|c|c|c|}
\hline Phenomenon & $\begin{array}{l}\text { 1940s } \\
\text { MacCurdy }\end{array}$ & $\begin{array}{l}\text { 1970s-1980s } \\
\text { Armistead, } \\
\text { Varela, Alvar }\end{array}$ & $\begin{array}{l}\text { 1990s } \\
\text { Lipski, Coles, } \\
\text { Lestrade }\end{array}$ & $\begin{array}{l}\text { 1994-1998 } \\
\text { Varela-García }\end{array}$ & 2oth c. CIS \\
\hline $\begin{array}{l}\text { Predorsal dental /s/ } \\
\text { and seseo }\end{array}$ & + & $\begin{array}{l}+ \text { Armistead } \\
+ \text { Alvar }\end{array}$ & $\begin{array}{l}+ \\
+ \text { Coles (more } \\
\text { fronted) }\end{array}$ & + & + \\
\hline $\begin{array}{l}\text { Aspiration from } \\
\text { Latin or Arabic /f/ }\end{array}$ & $\begin{array}{l}\text { +/- aspirated } \\
\text { before ui/ue; } \\
\text { kept: facina } \\
\text { 'harina' }\end{array}$ & $\begin{array}{l}\text { + Armistead } \\
\text { + Alvar (also } \\
\text { bilabial) }\end{array}$ & + Coles & $\begin{array}{l}+ \text { aspirated } \\
\text { before ui/ue }\end{array}$ & + \\
\hline / $\mathrm{x} /$ aspiration & $\begin{array}{l}\text { + deletion } \\
\text { word final }\end{array}$ & $\begin{array}{l}\text { + Armistead } \\
+ \text { Alvar }\end{array}$ & + & + & + \\
\hline $\begin{array}{l}\text { Syllable and word } \\
\text { final /-s/ aspiration } \\
\text { and loss }\end{array}$ & $\begin{array}{l}\text { + aspiration } \\
\text { even intervo- } \\
\text { calically; } \\
\text { sometimes } \\
\text { deleted before } \\
\text { pause }\end{array}$ & $\begin{array}{l}\text { + Armistead } \\
\text { + Alvar (elision } \\
\text { in plural nouns) }\end{array}$ & $\begin{array}{l}\text { + Lipski (word } \\
\text { final > deleted / } \\
\text { consonant cluster } \\
\text { > aspirated) } \\
\text { + Coles } \\
\text { + Lestrade }\end{array}$ & + & + \\
\hline $\begin{array}{l}\text { Voiceless stop } \\
\text { gemination after /s/ }\end{array}$ & - & + Alvar & + Coles & + & + \\
\hline $\begin{array}{l}\text { Vocalization /l/ and } \\
\text {-/er/ word final } \\
\text { before consonant > } \\
\text { /f/ }\end{array}$ & + & + Alvar & & + & + \\
\hline $\begin{array}{l}\text { /1/ word final before } \\
\text { consonant }>/ \mathrm{r} /\end{array}$ & + sporadically & $\begin{array}{l}+ \text { Alvar } \\
\text { (infinitive) }\end{array}$ & $\begin{array}{l}+ \text { Coles (also } / \mathrm{r} /> \\
/ \mathrm{l} /)\end{array}$ & + & + \\
\hline$/ \mathrm{r} /$ word final $>/ \mathrm{l} /$ & - & + & + Coles & + & + \\
\hline $\begin{array}{l}\text { /-l/ /-r/ word final } \\
\text { loss }\end{array}$ & + & + Alvar & + Coles & + & + \\
\hline $\begin{array}{l}\text { /-l/ /-r/ syllable and } \\
\text { word final } \\
\text { maintenance/ } \\
\text { aspiration }\end{array}$ & + & -Alvar & $\begin{array}{l}+ \text { Coles } \\
\text { (germination) }\end{array}$ & + sporadically & + \\
\hline Metathesis of /-r/ & + & $\begin{array}{l}\text { + Armistead } \\
+ \text { Alvar }\end{array}$ & $\begin{array}{l}\text { + Lipski } \\
\text { + Coles }\end{array}$ & + & + \\
\hline $\begin{array}{l}\text { Epenthetic } \\
\text { intervocalic /d/ /r/ }\end{array}$ & + & + Alvar & + & + & \\
\hline
\end{tabular}




\begin{tabular}{|c|c|c|c|c|c|}
\hline $\begin{array}{l}\mathrm{v} / \mathrm{r} / \mathrm{v}->\text { voiced } \\
\text { fricative; alveolar } \\
\text { like English }\end{array}$ & + group /tr/ & & - Lipski & - & \\
\hline Intervocalic /d/ kept & $+/-$ & + Alvar & & + & + \\
\hline $\begin{array}{l}\text { Loss of /-d/ /-n/ in } \\
\text { word final position }\end{array}$ & + & $\begin{array}{l}\text { + Armistead } \\
+ \text { Alvar }\end{array}$ & $\begin{array}{l}\text { + Coles (also } \\
\text { alveolar [d]) }\end{array}$ & + & + \\
\hline $\begin{array}{l}\text { Loss of intervocalic } \\
\text { /b/ in imperfect } \\
\text { verb 'ir' }\end{array}$ & & & & $+/-$ & + \\
\hline $\begin{array}{l}\text { Epenthetic / } \mathrm{n} \text { / in } \\
\text { existential pronoun }\end{array}$ & + & $\begin{array}{l}\text { + Armistead } \\
+ \text { Alvar }\end{array}$ & + & + & $\begin{array}{l}\text { + deleted /s/ } \\
\text { before /bdg/- } \\
>\text { /n/ }\end{array}$ \\
\hline $\begin{array}{l}\text { Loss of intervocalic } \\
\text { /b/ in imperfect }\end{array}$ & + & + Alvar & & + & \\
\hline $\begin{array}{l}\text { Opposition } / \mathrm{j} /-/ K / \text { : } \\
\text { yeísmo-confusion }\end{array}$ & $\begin{array}{l}\text { + yeísmo / } \\
\text { distinction }\end{array}$ & $\begin{array}{l}\text { + Armistead } \\
\text { + Alvar (yeísmo) }\end{array}$ & + Coles & + yeísmo & $\begin{array}{l}\text { + yeísmo } \\
\text { + lleísmo }\end{array}$ \\
\hline $\begin{array}{l}\text { Consonantal /g/+ u } \\
</ \text { b/ }\end{array}$ & + & + Alvar & & + & + \\
\hline $\begin{array}{l}\text { Deletion of } \\
\text { intervocalic /d/ }\end{array}$ & + & + Alvar & $\begin{array}{l}\text { + Coles (-ado } \\
\text { endings, décimas } \\
\text { and conversation) }\end{array}$ & + & + \\
\hline $\begin{array}{l}\text { Simplification of } \\
\text { consonantal groups } \\
\text { /-bs/ /-ks/ /-ps/ } \\
\text { /-ns/ /-ng/ /-nx/ } \\
\text { /-dm/ /-dk/ /-db/ } \\
\text { /-rl/ /-rn/ aspirated }\end{array}$ & + & + Alvar & + & + & + \\
\hline $\begin{array}{l}\text { Voicing /ptk/ inter- } \\
\text { vocalically (or } \\
\text { between liquids) }\end{array}$ & + sporadically & & + Coles & + & + \\
\hline $\begin{array}{l}\text { Deletion of /b/ } \\
\text { intervocalically }\end{array}$ & + & & & + & \\
\hline $\begin{array}{l}/ \mathrm{d} / / \mathrm{r} / \\
\text { neutralization }\end{array}$ & & & + Lestrade & - & \\
\hline Final velar $-n$ & $\begin{array}{l}+/ \text { - before } \\
\text { pause and /o/ } \\
\text { /u/ }\end{array}$ & $\begin{array}{l}\text { + Alvar (very } \\
\text { velar) }\end{array}$ & $\begin{array}{l}\text {-Lipski } \\
\text { + Coles }\end{array}$ & + & + \\
\hline Alveolar -n & + & & + Lipski & + & + (rural) \\
\hline
\end{tabular}

Table 3. Isleño Spanish consonantal system

\subsection{Morphology}

Tables 4 to 6 portray the description of IS's nominal and verbal morphology from the 1940 s. 


\begin{tabular}{|c|c|c|c|c|c|}
\hline Phenomenon & $\begin{array}{l}\text { 1940s } \\
\text { MacCurdy }\end{array}$ & $\begin{array}{l}\text { 1970s-1980s } \\
\text { Armistead, } \\
\text { Varela, Alvar }\end{array}$ & $\begin{array}{l}\text { 1990s } \\
\text { Lipski, Coles, } \\
\text { Lestrade }\end{array}$ & $\begin{array}{l}\text { 1994-1998 } \\
\text { Varela-García }\end{array}$ & 20th c. CIS \\
\hline $\begin{array}{l}\text { Subject pronouns } \\
\text { yo, tú, él, ella, } \\
\text { usted, nosotros, } \\
\text { ustedes, ellos }\end{array}$ & + & + Alvar & $\begin{array}{l}\text { - Lipski } \\
\text { - Coles } \\
\text { - Lestrade } \\
\text { (reduction to 3rd } \\
\text { person) }\end{array}$ & + & + \\
\hline $\begin{array}{l}\text { Ustedes instead of } \\
\text { vosotros }\end{array}$ & + & $\begin{array}{l}\text { + Armistead } \\
\text { + Varela } \\
+ \text { Alvar }\end{array}$ & + & + & + \\
\hline $\begin{array}{l}\text { Feminine gender } \\
\text { assigned to words } \\
\text { from Greek ending } \\
\text { in -ma }\end{array}$ & + & $\begin{array}{l}+ \text { Alvar (in } \\
\text { many varieties } \\
\text { of American } \\
\text { Spanish) }\end{array}$ & $\begin{array}{l}\text { + Lestrade } \\
\text { (hypercorrection, } \\
\text { la idioma) }\end{array}$ & $+($ la idioma $)$ & + \\
\hline $\begin{array}{l}\text { Gender } \\
\text { reassignment to } \\
\text { nouns ending in } \\
-e\end{array}$ & + la menaja & $\begin{array}{l}\text { + Alvar (la } \\
\text { liendra) }\end{array}$ & $\begin{array}{l}+ \text { morphology } \\
\text { reduction }\end{array}$ & + & + \\
\hline $\begin{array}{l}\text { Final /s/ - > } \\
\text { results in loss of } \\
\text { plural marking }\end{array}$ & - & $\begin{array}{l}\text { + Alvar } \\
\text { (deletion but } \\
\text { plural } \\
\text { morphology } \\
\text { kept) }\end{array}$ & + Lipski & - & - \\
\hline Demonstratives & + & + & + & + & + \\
\hline Possessives & + & + & + & + & + \\
\hline $\begin{array}{l}\text { Comparatives / } \\
\text { superlatives }\end{array}$ & & + & + & + & + \\
\hline $\begin{array}{l}\text { Addressing and } \\
\text { suffix derivation }\end{array}$ & & + & + & + & + \\
\hline $\begin{array}{l}\text { don, señor, } \\
\text { vuestra merced } \\
\text { /su merced, } \\
\text { maestro, tío }\end{array}$ & $\begin{array}{l}\text { + don, señor, } \\
\text { tío }\end{array}$ & + & + & $\begin{array}{l}\text { + don, señor, } \\
\text { tío }\end{array}$ & $\begin{array}{l}\text { + don, señor, } \\
\text { tío }\end{array}$ \\
\hline -ito, -illo, -ico & + & + & + & + illo & + not stratified \\
\hline $\begin{array}{l}\text { Nicknames to } \\
\text { address members } \\
\text { of popular social } \\
\text { classes }\end{array}$ & $\begin{array}{l}+ \text { not } \\
\text { associated to } \\
\text { popular class }\end{array}$ & + & + & + & + \\
\hline naiden & + & + Alvar & + & + & + \\
\hline Suffix -ear & + & + Alvar & + & + & + \\
\hline Suffix -ada & + & & & + & + \\
\hline Suffix -era/a & + & + & + & + & + \\
\hline
\end{tabular}

Table 4. Isleño Spanish morphology

The consensus is that the nominal and verbal morphology were functionally maintained in Isleño Spanish at least until the 1990s (MacCurdy, 1948; Armistead, 1981; Alvar, 1998).14 IS uses usted and ustedes instead of vosotros and vos. There is instability and irregular gender 
reassignment in nouns ending in -e as in el costumbre, lo legumbre, liendra 'liendre', and linda 'linde' (Alvar, 1998, 48). One of the subjects, Irvan Perez, offered a full grammatical explanation that might reflect reduction by overgeneralization of the basic -o/- $a$ rule in gender assignment in nouns ending in $-a$ such as el/la pirata where the article and qualifiers disambiguate: "it is el pirato; if it was a female, it would be la pirata but Jean Laffite was a man".

Alvar profusely documented plural las liendrah in ALEICan proving that this result, at least in its plural form, is not exclusively of IS' origination. Masculine nouns from Greek taking feminine articles (la mapa, la idioma, la problema) were also found (Alvar, 1998, 47). This last result which would prompt us to think about English influence has been documented in the Hispanic speaking world. ${ }^{15}$

Aspiration and deletion of plural $-s$ is generalized. Alvar (1998, 43) claims almost categorical /-s/ deletion in the plural: peaso, ropa, macho, diente. As he says (1998, 52), "en posición final absoluta, lo normal es su pérdida [...] El plural nunca tiene marca fonológica". I attested both aspiration and deletion in plural marking. Lipski (1985b, 1990, 1993) also claims loss of singular/plural contrast. MacCurdy $(1950,43)$ mentioned the common double plural ending in -es in words ending in accented vowels (pieses, sofases) that my study confirmed as well.

The demonstrative, possessive, and indefinite pronoun systems exist in IS. La and las are used as direct object pronouns and le and les in indirect functions. MacCurdy (1950, 43) attested a feminine cuala and a masculine cualo relative pronouns. I found cuala and quien in masculine plural and naiden. Suffixes -ito and -illo are documented, but -illo is most commonly used. Speakers used derivational morphology -ear, -ada and -era/ero to create words to refer to actions, occupations, and/or groups. Irvan Perez used neologism protestosa instead of the usual 'protestona.'

Personal leísmo is today attested in the Canary Islands. This appears to be an innovation never reported in IS where the clitic system maintains functional contrast (table 5).

\begin{tabular}{|c|c|c|c|c|c|}
\hline Phenomenon & $\begin{array}{l}\text { 1940s } \\
\text { MacCurdy }\end{array}$ & $\begin{array}{l}\text { 1970s-1980s } \\
\text { Armistead, } \\
\text { Varela, Alvar }\end{array}$ & $\begin{array}{l}1990 \text { os } \\
\text { Lipski, Coles, } \\
\text { Lestrade }\end{array}$ & $\begin{array}{l}\text { 1994-1998 } \\
\text { Varela-García }\end{array}$ & 20th c. CIS \\
\hline $\begin{array}{l}l o \text { and } l e \text { as direct object, } \\
\text { indirect object }\end{array}$ & + & + & + Lestrade & + & + \\
\hline Personal leísmo & - & - & & - & + \\
\hline $\begin{array}{l}\text { Leísmo for not animated } \\
\text { referent (- human) }\end{array}$ & - & - & & - & - \\
\hline les with deleted /-s/ & - & & & + & + \\
\hline
\end{tabular}

Table 5. Clitics 
Concerning the verbal morphology (table 6), IS has indicative, subjunctive, conditional, and imperative moods. Isleño speakers have maintained most tenses in the indicative, although they prefer analytical periphrastic forms over the synthetic imperfect future. They also use imperfect subjunctive. Some peculiarities include existential estar, había 'tenía', víamos 'veíamos', and archaic verb dir 'ir'. These anomalies are consistently found in the Canary Islands (Alvar, 1959, 1968, 1993). As innovations, Alvar (1998, 49) cites some verbal forms that I also documented in this sample: salgueré 'saldré, disimos 'dijimos', disieron 'dijeron'. Lipski (1990, 2008), Coles (1991, 1999) and Lestrade (2002) report simplification of subject pronoun system and verbal forms in favor of third person. Lipski also claimed loss of conjunctions and prepositions.

\begin{tabular}{|c|c|c|c|c|c|}
\hline Phenomenon & $\begin{array}{l}\text { 1940s } \\
\text { MacCurdy }\end{array}$ & $\begin{array}{l}1970 s-1980 \text { os } \\
\text { Armistead, Varela, } \\
\text { Alvar }\end{array}$ & $\begin{array}{l}1990 \mathrm{~S} \\
\text { Lipski, Coles, Lestrade }\end{array}$ & $\begin{array}{l}\text { 1994-1998 } \\
\text { Varela-García }\end{array}$ & 20th c. CIS \\
\hline $\begin{array}{l}\text { Present } \\
\text { indicative }\end{array}$ & + & + & $\begin{array}{l}\text { + Lipski } \\
\text { + Lestrade }\end{array}$ & + & + \\
\hline $\begin{array}{l}\text { Present } \\
\text { progressive }\end{array}$ & & & $\begin{array}{l}\text { + Lipski } \\
\text { + Lestrade }\end{array}$ & + & + \\
\hline Reflexive verbs & + & & $\begin{array}{l}\text { + Lipski } \\
\text { + Lestrade }\end{array}$ & + & + \\
\hline Present perfect & & + Alvar & + Lestrade & + & + \\
\hline Preterite & & + Alvar & $\begin{array}{l}\text { + Lipski } \\
\text { + Lestrade }\end{array}$ & + & + \\
\hline Imperfect & + & + Alvar & $\begin{array}{l}\text { + Lipski } \\
\text { + Lestrade }\end{array}$ & + & + \\
\hline Subjunctive & + & + Alvar & + Lestrade & + & + \\
\hline Conditional & & + Alvar & + Lestrade & + & + \\
\hline Adverbs & + & + & + & + & + \\
\hline $\begin{array}{l}\text { Existential estar } \\
\text { and the opposite }\end{array}$ & & & + Lipski & + & + \\
\hline $\begin{array}{l}\text { víamos } \\
\text { (veíamos) }\end{array}$ & + & & + Lestrade & + & \\
\hline (d)ir & + & + Alvar & $\begin{array}{l}\text { + Lipski } \\
\text { + Lestrade }\end{array}$ & + & \\
\hline había for tenía & & & & + & \\
\hline Conjunctions & + & & + Lipski (reduction) & + & + \\
\hline Prepositions & + & & $\begin{array}{l}\text { + Lipski (reduction) } \\
\text { + Lestrade (reduction) }\end{array}$ & + & + \\
\hline
\end{tabular}

Table 6. Verbal morphology 


\subsection{Syntax}

Table 7 displays syntactic features of IS that are different from CIS. Alvar $(1998,49)$ mentions a few discrepancies in IS syntax. He finds minimal English interference and word order innovations such as antes de nosotros venir 'before we come' or los abuelos nuestros 'our grandparents'. He did not report significant syntactic differences between Canary Spanish and the Louisiana dialect. Lipski (1985a, 1985b, 1987, 1990) reported syntactic changes as a result of English contact. I will discuss it in section 7.

\begin{tabular}{|c|c|c|c|c|c|}
\hline Phenomenon & $\begin{array}{l}\text { 1940s } \\
\text { MacCurdy }\end{array}$ & $\begin{array}{l}\text { 1970s-1980s } \\
\text { Armistead, Varela, } \\
\text { Alvar }\end{array}$ & $\begin{array}{l}\text { 1990s } \\
\text { Lipski, Coles, } \\
\text { Lestrade }\end{array}$ & $\begin{array}{l}\text { 1994-1998 } \\
\text { Varela-García }\end{array}$ & 2oth c. CIS \\
\hline \multicolumn{6}{|c|}{ Word order } \\
\hline $\begin{array}{l}\text { antes de nosotros } \\
\text { venir }\end{array}$ & & + Alvar & & + & \\
\hline los abuelos nuestros & & + Alvar & & + & \\
\hline $\begin{array}{l}\text { y él me dijo las cosas } \\
\text { cómo hacer }\end{array}$ & & & + Lipski & + & + \\
\hline
\end{tabular}

Table 7. Isleño Spanish syntax

\subsection{Lexicon}

In the 1940s, MacCurdy (1948) described IS lexicon as mainly popular Andalusian and Caribbean vocabulary. While MacCurdy highlighted non-standard words to emphasize the uniqueness of the Isleño language, thirty years later Alvar $(1993,1998)$ would examine the rich shared lexicon between Spain and Louisiana to claim the unity and vitality of this American variety. He emphasized that common Spanish was the basis of IS: "hablaban un buen español, como lo hablan hoy las gentes de sus Islas, o los labrantines de Ávila, o los pastores de La Mancha” (1998, 97).

Both scholars agree on the presence of Spanish archaisms, ${ }^{16}$ hispanized Louisiana Creole French and English words, Canary Islands vocabulary, Portuguese words, and Latin Americanisms (MacCurdy, 1948, 45-47). At the time of his research, MacCurdy noted that, "contrary to expectations, there are few Hispanized English words in the vocabulary" (1948, 47). Fifty years later, the same situation, also noted by Coles (1999), is encountered: fluent Isleños appear to have kept their two phonetic inventories apart due to their balanced bilingualism. A few examples of some of those influences are depicted in table 8 . They are taken from Lipski (2008), MacCurdy (1948) and Alvar (1998). 


\begin{tabular}{|c|c|c|}
\hline Origin & Example & Glossary \\
\hline $\begin{array}{l}\text { Archaic, rural and } \\
\text { analogical }\end{array}$ & asina, naide, probe, entuavía & \\
\hline French & $\begin{array}{l}\text { bayul, *fruí, lacre, tanta, cribis, } \\
* * * \text { plato, }{ }^{* * *} \text { mareta }\end{array}$ & ${ }^{*}$ fr. fourbir, ${ }^{* *}$ fr. plateau, ${ }^{* * *}$ fr. marais \\
\hline Anglicisms & $\begin{array}{l}\text { guachimán, grosería, *rif(l)e, }{ }^{* * * *} \text { mape, } \\
\text { troleá, }{ }^{* * * * *} \text { farmero }\end{array}$ & ${ }^{*}$ reef, ${ }^{* *}$ mop, ${ }^{* * *}$ trawl, ${ }^{* * * *}$ farmer \\
\hline Canary Islands & $\begin{array}{l}\text { guagua, gofio, faca, }{ }^{*} \text { cuero, }{ }^{*} \text { quemar, } \\
{ }^{*} \text { colorao }\end{array}$ & $\begin{array}{l}{ }^{*} \text { Migrated from the Canary Islands in } \\
\text { the } 18 \text { th century (Alvar, } 1998,99)^{17}\end{array}$ \\
\hline Neologisms & capotiarse & capota $<19$ th century \\
\hline $\begin{array}{l}\text { Andalusisms and } \\
\text { Canarisms }\end{array}$ & pehtina & bestina \\
\hline Latin Americanisms & jaiba, barbú & \\
\hline Indigenous voices & jícara, maíz & teacup, corn \\
\hline $\begin{array}{l}\text { Lusitanisms/ } \\
\text { Galician }\end{array}$ & ${ }^{*}$ bandola, ${ }^{*}$ devaso, ${ }^{*}$ encetar, ${ }^{* *}$ enciña & ${ }^{*}$ In the CIs, ${ }^{* *}$ evergreen oak \\
\hline
\end{tabular}

Table 8. Origin of Isleño lexicon

Trying to identify shared terminology with the Canary Islanders, Alvar (1976, 1985, 1993) asked questions from the ALEICan and nautical terminology to a group of Isleños elders. He found numerous shared words, but what caught his attention was that most words in IS are found not only in everyday CIS, but also, and most importantly, in the standard, common vocabulary used across the Spanish speaking world. In Alvar (1998, 121-129), he also described the nautical terminology in Louisiana, but only reported on Irvan Perez's answers to questions registered in the ALEICan and in the questionnaire in the Léxico de los marineros peninsulares, as seen in table 9 below.

\begin{tabular}{|l|l|l|}
\hline \multicolumn{1}{|c|}{$\begin{array}{c}\text { ALEICan / Léxico de los } \\
\text { marineros peninsulares }\end{array}$} & \multicolumn{1}{|c|}{ Irvan Perez } & \multicolumn{1}{c|}{ CIS } \\
\hline viento de proa & caraviento & viento a la cara \\
\hline viento de popa & viento d'atrá & viento de popa \\
\hline levar anclas & recoher/levantá & levar \\
\hline abordar & ponelo de lao & atracar \\
amarrar & marrá & atracar \\
\hline encallar & embarrancá & encallar \\
cabecear & picá de proba & cabeciando \\
\hline cargadero & cargadero & atracadero \\
roda & rueda & ro(d)a \\
timón & ruea de goberná & timón \\
\hline balde de madera & paquete & balde \\
sonda & sondaero & escandallo \\
remos pareados & parel & pairé \\
remar & hala & bogar \\
\hline curricán & liña rahtro & corricá \\
(pescado) azul & sangrero & azul, negro \\
\hline
\end{tabular}

Table 9. Lexicon of the Peninsular sailors 
Alvar also annotated shared vocabulary with the Canary Islands, wondering when it had entered the Isleños' lexicon $(1998,12-13) .{ }^{18}$ He claimed the first settlers were not fishermen and thus the large body of shared vocabulary might have been introduced in Louisiana by immigrants during the following 150 years after the initial voyages. This fact would help understand such language maintenance and cohesion: initial isolation helped maintain archaic language patterns and Portuguese, Galician, Andalusian, Canarian and other Peninsular vocabulary. Then, neighboring French Creole and English enriched this dialect. However, renewed Spanish language influx from Latin America and Spain allegedly helped the Isleño dialect keep its unity while surrounded by English.

IS speakers also have neologisms which respond to the need to name their reality (Alvar, 1998, 127). Words suffer semantic extensions or impoverishment: bastinas, 'peces de cuero, de fuerte olor', become pehtina by association with peste, and relámpago associated to lámpara becomes relámparo. The use of flexional morphology to create adjectives and verbs denotes a dialect capable of innovation.

In sum, the vitality of the Isleños' vocabulary is undeniable. Despite the system instability, speakers use morphemes, suffixes, semantic change, and polysemy to preserve the words alive and to create new ones in a mix of conservatism and innovation.

\subsection{Language contact}

The following section and tables 10 to 12 present main language changes that occurred in IS as a result of language contact with English. For some scholars, they are expressions of linguistic innovations, while other researchers see language reduction and loss.

Despite bilingual speakers managing to keep their two languages apart, given that IS has survived in Anglo-speaking conclave, English interference was inevitable. I attested transferences in lexical, borrowing (politiciano 'politician') and derivational morphology instances (troliar 'to trawl', trampiar 'to trap'), e- aphaeresis as in scalera 'escalera', and English syllable and word final velar /l/. Schwas are occasionally heard in unstressed vowels. There is phonetic borrowing and occasional interference without morphological repercussions. Often, lexical borrowings are phonetically hispanized. 


\begin{tabular}{|c|c|c|c|c|}
\hline Phenomenon & $\begin{array}{l}\text { 1940s } \\
\text { MacCurdy }\end{array}$ & $\begin{array}{l}\text { 1970s-1980s } \\
\text { Armistead, Varela, } \\
\text { Alvar }\end{array}$ & $\begin{array}{l}\text { 1990s } \\
\text { Lipski, Coles, Lestrade }\end{array}$ & $\begin{array}{l}\text { 1994-1998 } \\
\text { Varela-García }\end{array}$ \\
\hline $\begin{array}{l}\text { Transference (lexical } \\
\text { borrowing, politiciano) }\end{array}$ & + & + Alvar & $\begin{array}{l}\text { + Lipski } \\
\text { + Coles }\end{array}$ & + \\
\hline $\begin{array}{l}\text { Loan translation } \\
\text { (grosería 'groceries', } \\
\text { marqueta 'market', } \\
\text { lonchar 'to have lunch') }\end{array}$ & + & + Armistead & $\begin{array}{l}\text { + Lipski } \\
\text { + Coles }\end{array}$ & + \\
\hline $\begin{array}{l}\text { /e/ before /s/ apheresis } \\
\text { (scalera) }\end{array}$ & + & & + Lestrade & + \\
\hline $\begin{array}{l}\text { English syllable and } \\
\text { word-final dark /l/ }\end{array}$ & & & $\begin{array}{l}\text { + Lipski (in younger } \\
\text { speakers) } \\
\text { - Alvar }\end{array}$ & $\begin{array}{l}\text { + older speakers } \\
\text { (sporadically) }\end{array}$ \\
\hline $\begin{array}{l}\text { Schwa in unstressed } \\
\text { vowels }\end{array}$ & $\begin{array}{l}\text { Unstable } \\
\text { unstressed } \\
\text { vowels }\end{array}$ & & $\begin{array}{l}\text { + Lipski (also in CIS) } \\
\text { + Coles (rare) } \\
\text { + Lestrade (frequent) }\end{array}$ & $\begin{array}{l}\text { schwa in } \\
\text { unstressed vowels }\end{array}$ \\
\hline $\begin{array}{l}\text { Hispanized } \\
\text { pronunciation }\end{array}$ & & & + Lipski & + \\
\hline
\end{tabular}

Table 10. Language phonetic contact

Lipski (1985a, 1987, 1993) documented linguistic behavior that he explained in terms of language loss and reduction similar to processes that occur in pidgins and creoles: reduction of verb conjugation to a 3 rd person while also categorical use of redundant subject pronouns following English rules. According to him, Isleños' use of generic subject pronouns tú/usted for impersonal subject is a sign of nominal morphology reduction and interference from English constructions. This use, nonetheless, is commonly found in Caribbean Spanish. Use of a gerund after an infinitive is also a result of English intrusion in IS verbal morphology.

Likewise, gender instability and reassignment described by MacCurdy (1948) and Alvar (1998) is explained by Lipski (1985a, 1987, 1993), Coles (1999) and Lestrade (2002) as gender loss and reduction of inflectional morphology. These scholars also described conjunction and prepositional reduction which I could not attest.

Linguistic innovation as a result of language contact in syntactic lexicalized transference expressions with 'para atrás' patrás is attested throughout Spanish varieties of the United States. This development points out to generalized structural innovation. All researches agree, as well, on the use of the suffix -iar < ear as an expression of dialect vitality and creativity. Code-switching is uncommon, and when it happens it does not affect the communication and is socially and communicatively acceptable.

The phenomena described in table 11 are taken from Lipski (1987): 


\begin{tabular}{|c|c|c|c|c|}
\hline Phenomenon & $\begin{array}{l}\text { 1940s } \\
\text { MacCurdy }\end{array}$ & $\begin{array}{l}\text { 1970s-1980s } \\
\text { Armistead, Varela, Alvar }\end{array}$ & $\begin{array}{l}\text { 1990s } \\
\text { Lipski, Coles, Lestrade }\end{array}$ & $\begin{array}{l}\text { 1994-1998 } \\
\text { Varela-García }\end{array}$ \\
\hline $\begin{array}{l}\text { Reduction of verb } \\
\text { conjugation to a } 3 \text { rd } \\
\text { person }\end{array}$ & - & - Alvar & $\begin{array}{l}\text { + Lipski } \\
\text { + Lestrade }\end{array}$ & - \\
\hline $\begin{array}{l}\text { Definite article } \\
\text { dropping in generic } \\
\text { subject/object } \\
\text { position }\end{array}$ & & & $\begin{array}{l}\text { + Lipski (oldest speakers) } \\
\text { + Lestrade (frequent, but } \\
\text { when kept they have } \\
\text { retained the plural marking } \\
\text { in noun phrases; is from } \\
\text { French influence) }\end{array}$ & - \\
\hline $\begin{array}{l}\text { Gerund after } \\
\text { infinitive }\end{array}$ & & & + Lipski (sporadically) & - \\
\hline $\begin{array}{l}\text { Generic use of } \\
\text { subject pronouns } \\
\text { tú/usted for } \\
\text { impersonal subject }\end{array}$ & & & + Lipski (frequent) & + frequent \\
\hline $\begin{array}{l}\text { Redundant subject } \\
\text { pronouns following } \\
\text { the English pattern }\end{array}$ & & - Alvar & $\begin{array}{l}\text { + Lipski } \\
\text { + Lestrade (may constitute } \\
\text { an early sign of universal } \\
\text { Spanish language loss due to } \\
\text { English) }\end{array}$ & - \\
\hline $\begin{array}{l}\text { Conjunction } \\
\text { reduction }\end{array}$ & - & & + Lipski & - \\
\hline $\begin{array}{l}\text { Preposition } \\
\text { reduction }\end{array}$ & & & $\begin{array}{l}\text { + Lipski } \\
\text { + Lestrade }\end{array}$ & - \\
\hline $\begin{array}{l}\text { Syntactic } \\
\text { transference } \\
\text { (expresions with } \\
\text { 'para atrás' patrás) }\end{array}$ & + & $\begin{array}{l}\text { + Varela } \\
\text { + Alvar }\end{array}$ & $\begin{array}{l}\text { + Lipski } \\
\text { + Coles } \\
\text { + Lestrade }\end{array}$ & + \\
\hline $\begin{array}{l}\text { Code-switching tags } \\
\text { '(alright', 'well') }\end{array}$ & & & + Lipski (often) & + \\
\hline $\begin{array}{l}\text { Suffix -iar +verb } \\
\text { (troliar 'trawl', } \\
\text { trapiar, trampiar } \\
\text { 'trap') }\end{array}$ & + & + Alvar & + Lipski & + \\
\hline $\begin{array}{l}\text { Transitive use of } \\
\text { verb gustar }\end{array}$ & & & $\begin{array}{l}\text { + Lipski } \\
\text { + Lestrade }\end{array}$ & - \\
\hline $\begin{array}{l}\text { Lexical calques } \\
\text { (preguntar por < } \\
\text { 'ask for', escuela alta } \\
\text { < 'high school') }\end{array}$ & $\begin{array}{l}+ \text { mape } \\
\text { <'mop' }\end{array}$ & + Alvar & + Lipski & + \\
\hline $\begin{array}{l}\text { Passive } \\
\text { constructions not } \\
\text { allowed in Spanish } \\
\text { (yo fui nacido) }\end{array}$ & & & + Lipski & + \\
\hline
\end{tabular}

Table 11. Morphological-syntactic contact

Syntactic calques, as in tenía buen tiempo 'pero uno lo pasaba bien' 'I had a good time', were registered, as well as code-switching instances as in Sí, yo soy el más viejo de to(do)s, de como 
dice... de to (do) el seventeenth century 'I'm the oldest', and passive constructions not allowed in Spanish, such as yo fui nacido 'I was born'.

\begin{tabular}{|l|l|l|l|l|}
\hline Phenomenon & $\begin{array}{l}\text { 1940s } \\
\text { MacCurdy }\end{array}$ & $\begin{array}{l}\text { 1970s-1980s } \\
\text { Armistead, Varela, } \\
\text { Alvar }\end{array}$ & $\begin{array}{l}\text { 1990s } \\
\text { Lipski, Coles, } \\
\text { Lestrade }\end{array}$ & $\begin{array}{l}\text { 1994-1998 } \\
\text { Varela-García }\end{array}$ \\
\hline $\begin{array}{l}\text { Syntactic calque ('pero uno lo pasaba bien, } \\
\text { tenía buen tiempo' 'I had a good time') }\end{array}$ & & & + Lipski & + \\
$\begin{array}{l}\text { English or Spanish translation (era muy } \\
\text { lihta, muy ehmart 'she was very smart' } \\
\text { (Lipski, 1987) }\end{array}$ & & & + Lipski & - \\
$\begin{array}{l}\text { Intrasentential (sí, yo soy el más viejo de } \\
\text { to(do)s. De cómo dice... de to(do) } e l \\
\text { seventeenth century 'I'm the oldest') }\end{array}$ & $\begin{array}{l}\text { + Lipski } \\
\text { (rare) }\end{array}$ & + rare \\
\hline
\end{tabular}

Table 12. Code switching

\section{Discussion}

Comparison between the phonological system that arrived in 1778 and IS phonology in its last stages confirms the system stability and its preserved structure, with features common in rural, archaic Spanish in Spain and in Latin America. Although there are language contact induced vocalic changes such as laxing and centering of Spanish vowels as in English schwa, and laxed and low vowel [i] even when it is tonic - similar to English L1 students learning Spanish phonetics-, the fact is that raising and vocalic lowering by assimilation and dissimilation are also common in popular Spanish, and lengthening also happens in many Spanish varieties. Sporadic tonic vowel lengthening was also recorded.

The 18th century vocalic features preserved in 2oth century IS are: a) vocalic timber changes in unstressed vowels; b) tendency to change hiatus into diphthong; c) hiatus preservation; d) diphthongs become hiatus; e) epenthetic yod; and f) yod loss. The same consonantal weakening and neutralization processes found in 18th century Canary Spanish can be attested in IS. Comparison of all phonetic data reveals a well-preserved and stable consonantal system in IS except for lleísmo, which appeared in 18th century Canary Spanish documents but is never found in Saint Bernard. The main difference is the loss of / $\mathrm{j} / \mathrm{-} / \mathrm{K} /$ opposition in favor of yeísmo in IS. 18th century Canary Spanish had already embraced modern phonic features that are found today in Spanish dialects in southern regions in Spain, in the Caribbean, and the lowlands in Latin America.

Almost every 18th century Canary Spanish morphosyntactic feature as attested by Medina López (1997), Morera (2004), and Corrales and Corbella (2004) was preserved in IS, but many have disappeared from contemporary Spanish educated speech. These characteristics are generally considered proper of rural and archaic Spanish dialects today such as traditional IS. 
Addressing forms have been maintained in both dialects, except for 'vuestra merced'; however, in IS, a community not sharply socially stratified, they have lost the social status stratification described in 18th century Spanish. Leísmo, documented in 18th century and in modern Canary Spanish (Álvarez Martínez 1987), is never found in IS. Personal leísmo appears to be a recent full-developing phenomenon in the Canary Islands. However, 18th century CIS lleísmo/ yeísmo distinction and today's archaic maintenance in La Gomera and El Hierro tell a different story.

The 18th century Canary Spanish which originated the IS dialect 200 years ago was advanced in its phonetics and more conservative in its morphosyntactic system. By the time IS was approaching extinction (2005), the language displayed a significant level of historical stability because most of the same 18th century Canary Spanish linguistic elements brought to Saint Bernard were still preserved by its last speakers. This evidence also characterizes IS as a historical, traditional and conservative variety.

Having addressed significant language maintenance from 1778 till 2000, a discussion on which linguistic features and functions the last speakers maintained from 1940 to 2000 will ensue. Section 6 shows consensus regarding stable tonic vowels and some instability in the atonic group. Alvar (1998) and Coles (1999) document lengthening of stressed vowels and so did I occasionally in stressed and in unstressed vowels. This could be due to English transference (Coles, 1999), or to Spanish heritage (Alvar, 1998). All scholars described IS unstressed vowels as unstable during the last 50 years; Lipski $(1987,1990)$, Coles (1999), and Lestrade (2002) reported, as innovations, on reduction and centralization from English influence, Coles in semi-speakers under 50, and the present study in occasional /e/ reduction in speakers older than 70 .

There is overall agreement regarding consonantal behavior over the last 50 years (Atlantic variety, weak consonantal system, neutralizations, seseo and yeísmo), but scholarly work reveals discrepancies. Whereas lack of word final velar $/ \mathrm{n} /$ is considered the only feature in which IS breaks away from akin dialects (Lipski, 1985b, 1990), word final /n/ velarization has been described by others (MacCurdy, 1948; Alvar, 1998). For Alvar (1998), however, the only unique feature of IS is $/ \mathrm{r} /$ metathesis.

In addition to this, Alvar (1998) documented two variants of the alveopalatal affricate phoneme, a strong palatal allophone (preferred in IS) and an adherent one, both also to be found in the Canary Islands today. I did not record the adherent allophonic realization. Finally, Alvar (1998) tells of a post-dental ce as in ceceo pronunciation in Saint Bernard. I detected a ciceante pronunciation in Irvan Perez and ceceo in Allen Perez. Future acoustic analysis is needed to confirm this finding.

At the time of IS approaching extinction, its fluent speakers were 70 and older. Joseph 'Chelito' Campo's, Irvan Perez's and Allen Perez's bilingualism can be described as stable despite IS's severely reduced social domains. No study claimed total break in IS continuous 
use. All fluent speakers maintained strong and frequent contact within their primary social network and interacted in their ethnic language daily. Although they did not need IS in intragroup functional communication, they chose to use their L1 along with English as an ethnolinguistic marker and as expression of identity, loyalty and community symbolic norm. IS' last fluent speakers functionally maintained it as a linguistic system: "una lengua viva”, "un vibrante español”, "hablaban un buen español”, in Alvar's words (1998), proving Dorian's claim that losing speakers in a dying language does not make the rest semi-speakers.

Most recent and fast changes affecting IS's lexicon, morphology and syntax have been claimed to be English/Spanish language contact induced. Occasional schwa in the face of assimilation and dissimilation and vocalic laxing, lexical borrowings, loan translations, syntactic lexicalized transference, code-switching tags, and lexical calques have been explained as examples of L1 loss in contact with English. But they can also be treated as instances of convergence and reduction in form and functional adjustment as hispanized pronunciation of English words also shows to facilitate switching from one language into another for daily communication purposes while still maintaining two separate systems (Gumperz and Wilson, 1971). Scholars never explained extensive lexicon-borrowing from Acadian French and IS phonetic adaptation into French as a sign of Isleño Spanish attrition. The difference now is that IS had lost most of its speakers, and even though alleged innovations were successfully incorporated, lack of speakers would impede diffusion of these innovations into IS's grammar.

Certain Spanish quality in Isleño English vowels, when using ethnolinguistic lexicon - of French, Nahualt, and Canary Spanish origin- in words such as jaiba, jaibero, pehe, décima, lacre, Johnito-, and intra-sentential code-switching point out to functional convergence between speaker's L1 and L2. A bilingual language mode approach, considering interactions between the L1 and the L2 languages' activation in a continuum, explains that when both languages, IS and English, were regularly active, language mixing, codeswitching and interferences were recurrent and socially acceptable, eventually enabling L1 grammar access and limiting L2 massively replacing L1 features. This, in turn, might have helped Isleños' L1 preservation (Schmid, 2007, 137-151; Paradis, 2004). Looking at L1 behavior in a bilingual continuum helps describe attrition and maintenance processes within a comprehensive linguistic reality, despite L1 undeniable community loss and limitation to a small number of uses, domains and frequency.

Language loss processes that we attested include significant reduction in style shifting, hesitation when speaking (with pauses, filled pauses, repetitions, and self-repair), and noticeable reduction in complex subordination in favor of shorter, juxtaposed sentences. Lipski (1985a, 1985b, 1987, 1990), mainly, and Coles (1999), to a lesser extent, claimed reduction of subject pronouns to 3 rd person, loss in connecting words such as prepositions and conjunctions, and instances of non-Spanish word order among language reduction processes proper of pidgins and creoles. 
The overall community social structure changed the ethnic in-group's fabric, but norms did not, so IS remained as one of the language choices of the minority group (Fase, Jaspaert and Kroon, 1992, 6-7). Intermarriage impacted L1 loss and attrition by lack of intergenerational transmission and by limiting (home) domain of use if a speaker's partner's L1 language was different, as in Irvan Perez's case, whose wife did not speak IS. Irvan Perez did not transmit his L1 to his four daughters, and neither did he speak Spanish at home regularly; but his language loyalty and his frequent contact within his primary L1 network reinforced his L1 functional use. Although our speakers communicated in their L2, English, all of their lives, they never stopped speaking their L1.

L1 overall maintenance and loss in IS appears on table 13:

Areas of L1 language loss $\quad$ Areas of L1 language retention

\begin{tabular}{|c|c|}
\hline Total loss in speakers younger than 70 & 70 and up \\
\hline Self-reported lexical impoverishment & $\begin{array}{l}\text { Kingship terms } \\
\text { Local professional/technical terms (fishing, } \\
\text { trapping, farming) } \\
\text { Local flora and fauna } \\
\text { Household utensils } \\
\text { Daily conversational topics } \\
\text { Supernatural } \\
\text { Traditions and history } \\
\text { Future and intention } \\
\text { Wishes, fears, expectations } \\
\text { Emotions and subjective realm } \\
\text { Songs, proverbs, décimas, corridos } \\
\text { Transportation }\end{array}$ \\
\hline Occasional loss of por/para contrast in verbs & All word classes \\
\hline Significant reduction in style shifting & $\begin{array}{l}\text { Vernacular and casual speech } \\
\text { Décima performative style }\end{array}$ \\
\hline Occasional vocalic centralization (schwa) & $\begin{array}{l}\text { Vocalic assimilation and dissimilation } \\
5 \text { vocalic system } \\
\text { Vowel nasalization } \\
\text { Vowel lengthening, shortening } \\
\text { Vowel opening and closure } \\
\text { /e o/ raising and diphthongization } \\
\text { Diphthongs, triphthongs, hiatus }\end{array}$ \\
\hline Hesitation & Syllabifying, linking and synalepha \\
\hline Rare accent dislocation & $\begin{array}{l}\text { Prosody (stress, rhythm, intonation) } \\
\text { Hiatus into diphthongs }\end{array}$ \\
\hline Phonological and phonetic processes (-) & $\begin{array}{l}\text { Phonological contrast } \\
\text { Seseo and yeísmo } \\
\text { Spirantization } \\
\text { Assimilation } \\
\text { Lenition }\end{array}$ \\
\hline
\end{tabular}




\begin{tabular}{|c|c|}
\hline & $\begin{array}{l}\text { Voicing/devoicing } \\
\text { Metathesis } \\
\text { Aphaeresis } \\
\text { Apocope } \\
\text { Syncope } \\
\text { Prosthesis } \\
\text { Paragoge } \\
\text { Epenthesis } \\
\text { Rhotacism } \\
\text { Lambdacism }\end{array}$ \\
\hline Occasional gender reassignment & Gender agreement \\
\hline \multicolumn{2}{|l|}{ Loss of gender allomorphs } \\
\hline & Number agreement \\
\hline \multirow[t]{7}{*}{ Reduction to 3rd person (Lipski, Coles) } & Person agreement \\
\hline & Verbal agreement \\
\hline & Determinants \\
\hline & Pronouns \\
\hline & Verbs (TAM morphemes) (tense, aspect, mode) \\
\hline & Derivational morphology \\
\hline & Adverbs \\
\hline \multirow[t]{2}{*}{ Reduction (Lipski) } & Connecting words (prepositions, conjunctions) \\
\hline & Passive and active voice \\
\hline Reduction in complex sentences (subordination) & Syntactic recourses \\
\hline \multicolumn{2}{|l|}{ Syntactic borrowing from L2 } \\
\hline Word order changes (Lipski) & \\
\hline
\end{tabular}

Table 13. L1 overall maintenance and loss in IS

\section{CONCLUSIONS}

By the time of its death, Isleño Spanish had lost most of its speakers, but survived as L1 and was retained will full communicative competence by a handful of old bilingual speakers who used it in daily communication. It became an ethnolinguistic marker and identity expression. The dialect foundation retained very much of its original system: 1778 Canary Islands Spanish, except for personal leísmo and lleísmo, which never rooted in the new 
territory. There also exists some discrepancy among scholars as to which phonetic features are unique to Isleño Spanish: lack of velar $-n,-r$ metathesis, or a ciceante pronunciation.

During its life, IS experienced innovations that are recognizable mainly in the lexicon and in the morphology. Influence from English appears to have affected mostly the pronunciation and vocabulary. For some researchers, this English interference, which also reaches the syntax, represents language reduction and attrition; for us, language functional attrition is limited to significant loss of speakers, reduction in style shifting, self-reported lexicon impoverishment, hesitation and self-repairs in conversations and occasional sentence simplification. There have been linguistic innovations in the last 50 years in Isleño Spanish, but they did not prevent functional communication even across Spanish norms. Hispanized Isleño English as well as English interference in IS reveal bilingual communicative strategies that, likely, helped prevent L1 attrition.

All things considered, and for this small group of last Isleño Spanish speakers, we cannot claim dysfunctional attrition as our documented cases of linguistic loss did not significantly affect the speakers' competence to the point that deteriorated the communication. L1 never became stigmatized among Irvan Perez, Joseph 'Chelito' Campo and Allen Perez. We would rather speak of cosmetic attrition. These fluent speakers unanimously voiced limited, less appropriate, and poorer vocabulary than their parents and grandparents, but as a sign of linguistic insecurity, never as an expression of negative feelings towards a language for which they always manifested pride and loyalty. Although the community had shifted towards English, the preservation and functional maintenance of Isleño Spanish as a communicative system in the last speakers is undisputable.

\section{NOTES}

$1 \quad$ Remarkably, the community in general, and a few Isleños especially, put forward sustained efforts to preserve their heritage and created the Isleño Museum, organized décima festivals, practiced wood carving, and facilitated genealogy training. Likewise, Isleños-assisted researchers document their language preservation efforts.

2 Décima singers are traditionally males. Irvan Perez did not train any of his daughters (he did not have any sons) as décima singers but continued the patrilineal transmission.

3 Indirect measurement in the form of panel studies on small subgroups of a population by age to estimate the degree of language change or maintenance have been successfully used in language attrition research. The only requirement is that there are two or more sets of data collected at different times in which the same subgroup can be identified (De Vries, 1992, 220). Such smallscale panel designs in cohort analysis should get us even closer to gaining reliable knowledge on a complex phenomenon (De Vries, 1992, 221).

$4 \quad$ Transcriptions and reliability tests were conducted with bilingual speaker Leydi López Rosales. 
5 Data in the 1940 s was reported non-segregated by MacCurdy. In the 1970 s Armistead published written décimas, proverbs and sayings. In the 1980s Alvar at times identified Joseph 'Chelito' Campo and Irvan Perez's contributions individually as when he posed Irvan Perez questions from the vocabulary of Peninsular sailors, whereas in the 1990s Lipski and Coles offered phonetic annotations and morphosyntactic information elicited occasionally from Irvan Perez and Joseph 'Chelito' Campo. They all inferred group linguistic behavior from these individual speakers.

$6 \quad$ Joseph 'Chelito’ Campo learned English at age 11.

7 On occasion, they wrote the language when they composed décimas.

8 Organization of data presented challenges due to the deterioration of some of the audio cassettes I had used to record my interviews. Substantial data recovery, repairing and digitalization were necessary to carry out linguistic analysis. I thank Robert Mattison, from Learning and Technologies Services at the University of Wisconsin-Eau Claire, for his help.

9 See Schmidt (2011) and Köpke et al. (2007) for an in-depth discussion on challenges in current research, relevant methodological issues and important questions regarding first language attrition. See also De Vries (1992) for reflections on the limitations in research design and on measuring $\mathrm{L} 1$ attrition.

Díaz Alayón does not attribute this peculiar linguistic behavior to the fourteen years José de Viera y Clavijo resided outside the Canary Islands because he had written the first volume of Noticias de la Historia General de las Islas Canarias and part of the second by 1770 , prior to his residence in Madrid. There are numerous cases of laísmo in Noticias already. José Agustín Álvarez Rixo never visited the Peninsula so Díaz Alayón attributes his sporadic loísmo and rather frequent + and human leísmo cases to bibliographic influences.

11 Irvan's father, also a bilingual speaker, had composed décimas in Spanish and in English as well. Personal communication.

12 Alvar recorded his data in the 80s but published his work in 1998. In our panel study we are reporting data according to the decade in which speech was collected because this is crucial for us to show IS language changes across time. This is the convention we are using on our tables: we are not citing publication dates but rather the date (decade) of data collection.

13 The phenomena provided as examples in this and the following sections (6.1.1.3: diphthongs, and 6.1.1.4: hiatus) are taken from MacCurdy (1950, 27-29).

14 See Lipski (1985a, 1985b,1987,1990,1993) for his account on morphological and syntactic reduction in IS.

15 Also documented in Spain and in Latin America. See Rosenblat (1962).

16 For an excellent account of the vitality of archaisms in the Canary Islands lexicon, see Samper Padilla and Hernández Cabrera (1995).

17 These Spanish words, according to Alvar, migrated in the 18th century to Louisiana but are not part of common Spanish. Words that were brought from the Canaries and were adapted in Louisiana are el sartén, san huan 'junio', santiago 'agosto', lo legumbre, and arraclán' alacrán'. Other times words were created through analogy: papo del ojo 'párpado', doh mano yena 'almorzada', trapo fregá 'rodilla', tina lavá 'lavadero' (1998, 98-100). 
18 This common vocabulary is not regional but Pan-Hispanic and can be found across the Spanishspeaking world.

\section{REFERENCES}

ALMEIDA, M. 1992. "El español hablado en Canarias", Iberoamericana, 16(1), pp. 4-16.

ALVAR, M. 1959. El español hablado en Tenerife. Madrid: Consejo Superior de Investigaciones Científicas.

ALVAR, M. 1968. Estudios Canarios I. Las Palmas de Gran Canaria: Ediciones del Excmo. Cabildo Insular de Gran Canaria.

ALVAR, M. 1976. Atlas Lingüístico y Etnográfico de las Islas Canarias. Madrid: Ediciones del Excmo. Cabildo Insular de Gran Canaria.

ALVAR, M. 1985. Léxico de los marineros peninsulares. Madrid: Arco/Libros.

ALVAR, M. 1993. Estudios Canarios. Tomo II. Islas Canarias: Viceconsejería de Cultura y Deportes, Gobierno de Canarias.

ALVAR, M. 1998. El dialecto canario de Luisiana. Las Palmas de Gran Canaria: Universidad de Las Palmas de Gran Canaria, Servicio de Publicaciones.

ÁLVAREZ MARTÍNEZ, M. A. 1987. Rasgos gramaticales del español de Canarias. La Laguna: Instituto de Estudios Canarios.

ANDERSEN, R. W. 1982. "Determining the linguistic attributes of language attrition", in Lambert, R. D. and Freed, B. F. (eds.), The loss of language skills. Rowley, MA: Newbury House, pp. 83-118.

ARMISTEAD, S. G. 1979. "Hispanic traditional poetry in Louisiana", in Sánchez Romeralo, A., Catalán, D. and Armistead, S. G. (eds.), El romancero hoy: nuevas fronteras. Madrid: Cátedra Seminario Menéndez Pidal, pp. 147-158.

ARMISTEAD, S. G. 1981. "Spanish language and folklore in Louisiana”, La Corónica, 9(2), pp. 187-189.

ARMISTEAD, S. G. 1992. The Spanish tradition in Louisiana. Vol. 1: Isleño folkliterature. Newark, DE: Juan de la Cuesta.

COLES, F. 1999. Isleño Spanish. Newcastle: LINCOM Europa.

COLES, F. A. 1991. Social and linguistic correlates to language death: research from the Isleño dialect of Spanish. PhD thesis. Austin: University of Texas.

CORRALES, C. and CORBELLA, D. 2004. "Primeros testimonios e impresiones sobre el habla canaria”, Anuario de Estudios Atlánticos, 50, pp. 71-120.

DE VRIES, J. 1992. "Language maintenance and shift. Problems of measurement", in Fase, W., Jaspaert, K. and Kroon, S. (eds.), Maintenance and loss of minority languages. Amsterdam/ Philadelphia: John Benjamins, pp. 211-222.

DÍAZ ALAYÓN, C. 2005. "Sobre el comportamiento de los pronombres átonos en autores canarios de los siglos XVIII y XIX”, Revista de Filología de la Universidad de La Laguna, 23, pp. 79-96.

DORIAN, N. C. 1973. "Grammatical change in a dying dialect”, Language, 49(2), pp. 413-438. 
DORIAN, N. C. 1977. "The problem of the semi-speaker in language death", International Journal of the Sociology of Language, 12, pp. 23-32.

FASE, W., JASPAERT, K. and KROON, S. 1992. "Maintenance and loss of minority languages: introductory remarks", in Fase, W., Jaspaert, K. and Kroon, S. (eds.), Maintenance and loss of minority languages. Amsterdam/ Philadelphia: John Benjamins, pp. 3-13.

FISHMAN, J. A. 1972. "Language maintenance and language shift as a field of inquiry: revisited", in Dil A. S. (ed.), Language in sociocultural change: essays by J. A. Fishman. Stanford: Stanford University Press, pp. 76-132.

GUMPERZ, J. J. and WILSON, R. 1971. "Convergence and creolization: a case from the IndoAryan/Dravidian border in India”, in Hymes, D. (ed.), Pidginization and creolization of languages. London: Cambridge University Press, pp. 151-167.

HULSEN, M., DE BOT, K. and WELTENS, B. 2002. "'Between two worlds': social networks, language shift, and language processing in three generations of Dutch migrants in New Zealand”, International Journal of the Sociology of Language, 153, pp. 27-52.

KÖPKE, B. 2007. "Language attrition at the crossroads of brain, mind, and society", in Köpke, B. et al. (eds.), Language attrition: theoretical perspectives. Amsterdam/Philadelphia: John Benjamins, pp. 9-37.

KÖPKE, B. et al. 2007. Language attrition: theoretical perspectives. Amsterdam/Philadelphia: John Benjamins.

LABOV, W. 1963. "The social motivation of a sound change", Word, 19(3), pp. 237-309.

LABOV, W. 1984. "Field methods of the project on linguistic change and variation", in Baugh, J. and Sherzer, J. (eds.), Language in use: readings in sociolinguistics. Englewood Cliffs, N. J.: Prentice-Hall, pp. 28-53.

LAPESA, R. 1965. Historia de la lengua española. 9th ed. Madrid: Gredos.

LENNEBERG, E. H. 1967. Biological foundations of language. New York: Wiley.

LESTRADE, P. M. 1999. Trajectories in Isleño Spanish with special emphasis on lexicon. PhD thesis. Tuscaloosa: University of Alabama.

LESTRADE, P. M. 2002. “The continuing decline of Isleño Spanish in Louisiana”, Southwest Journal of Linguistics, 21(1), pp. 99-117.

LIPSKI, J. M. 1984. “The impact of Louisiana isleño Spanish on historical dialectology”, Southwest Journal of Linguistics, 7, pp. 102-115.

LIPSKI, J. M. 1985a. "Creole Spanish and vestigial Spanish: evolutionary parallels", Linguistics, 23(6), pp. 963-984.

LIPSKI, J. M. 1985b. "Reducción de /s/ y /n/ en el español isleño de Luisiana: vestigios del español canario en Norteamérica”, Revista de Filología de la Universidad de La Laguna, 4, pp. 125-133.

LIPSKI, J. M. 1987. "Language contact phenomena in Louisiana isleño Spanish”, American Speech, 62(4), pp. 320-331.

LIPSKI, J. M. 1990. The language of the Isleños: vestigial Spanish in Louisiana. Baton Rouge: Louisiana State University Press. 
LIPSKI, J. M. 1993. "Creoloid phenomena in the Spanish of transitional bilinguals", in Roca, A. and Lipski, J. M. (eds.), Spanish in the United States: linguistic contact and diversity. Berlin/New York: Mouton de Gruyter, pp. 155-182.

LIPSKI, J. M. 2008. Varieties of Spanish in the United States. Washington, D. C.: Georgetown University Press.

MACCURDY, R. R. 1948. The Spanish dialect in St. Bernard Parish, Louisiana. PhD thesis. Chapel Hill: University of North Carolina.

MACCURDY, R. R. 1950. The Spanish dialect in St. Bernard Parish, Louisiana. Albuquerque: The University of New Mexico Press.

MACCURDY, R. R. 1975. "Los 'isleños' de la Luisiana: supervivencia de la lengua y folklore canarios", Anuario de Estudios Atlánticos, 21, pp. 471-591.

MEDINA LÓPEZ, J. 1996. "La investigación lingüística sobre el español de Canarias", in Medina López, J. and Corbella Díaz, D. (eds.), El español de Canarias hoy: análisis y perspectivas. Frankfurt am Main/Madrid: Vervuert/Iberoamericana, pp. 9-48.

MEDINA LÓPEZ, J. 1997. "El español de Canarias a través de la documentación testamentaria (siglos XVI-XVIII)”, Boletín de Fílología, 36, pp. 163-189.

MORERA, M. 2004. "Algunas características del español canario del siglo XVIII”, Anuario de Estudios Atlánticos, 50, pp. 155-209.

PARADIS, M. 1993. "Linguistic, psycholinguistic, and neurolinguistic aspects of 'interference' in bilingual speakers: the activation threshold hypothesis", International Journal of Psycholinguistics, (9)2, pp. 133-145.

PARADIS, M. 2004. A neurolinguistic theory of bilingualism. Amsterdam/Philadelphia: John Benjamins.

PARADIS, M. 2007. "L1 attrition features predicted by a neurolinguistic theory of bilingualism", in Köpke, B. et al. (eds.), Language attrition: theoretical perspectives. Amsterdam/Philadelphia: John Benjamins, pp. 121-133.

POPLACK, S. 1979. Function and process in a variable phonology. PhD thesis. Philadelphia: University of Pennsylvania.

ROSENBLAT, A. 1962. "Morfología del género en español. Comportamiento de las terminaciones -o, -a”, Nueva Revista de Filología Hispánica, 16(1-2), pp. 31-80.

SAMPER, J. A. and HERNÁNDEZ, C. E. 2009. "El español isleño”, in López Morales, H. (coord.), Enciclopedia del español en los Estados Unidos: Anuario del Instituto Cervantes 2008. Madrid: Santillana, pp. 390-409.

SAMPER PADILLA, J. A. and HERNÁNDEZ CABRERA, C. E. 1995. "Vitalidad de supuestos arcaísmos léxicos en Gran Canaria”, Lingüística Española Actual, 17(2), pp. 229-238.

SANKOFF, G. 2006. "Age: apparent time and real time”, in Brown, K. (ed.), Encyclopedia of Language \& Linguistics. 2nd ed. Oxford: Elsevier, pp. 110-116.

SANKOFF, G. 2018. "Before there were corpora: the evolution of the Montreal French Project as a longitudinal study", in Wagner, S. E. and Buchstaller, I. (eds), Panel studies of variation and change. New York: Routledge, pp. 21-51. 
SCHMID, M. S. 2007. "The role of L1 use for L1 attrition”, in Köpke, B. et al. (eds.), Language attrition: theoretical perspectives. Amsterdam/Philadelphia: John Benjamins, pp. 135-153.

SCHMID, M. S. 2011. Language attrition. Cambridge: Cambridge University Press.

VARELA, B. 1986. “El español de Luisiana”, in Moreno de Alba, J. G. (ed.), Actas del II Congreso Internacional sobre el Español de América. Mexico, D. F.: Universidad Nacional Autónoma de México, pp. 273-277.

WEINREICH, U. 1963. Languages in contact: findings and problems. The Hague: Mouton.

\section{ACKNOWLEDGMENTS}

I would like to thank the Latin American Studies Program at the University of Wisconsin-Eau Claire for providing funding to help me transcribe the many hours of voice recordings on audiotape. Without their help I would not have been able to complete this project. I would also like to thank the Isleños community of Saint Bernard Parish for welcoming me through the summers I visited them and to pay tribute to the lives of three distinguished Isleños' community leaders and culture advocates: Joseph 'Chelito' Campo, Irvan Perez and Allen Perez whose voices made this study possible. They dedicated much of their lives to preserve Isleño Spanish and cultural identity and shared them with outside researches in their attempt to document their heritage knowing it was severely endangered. May this be my small contribution to their legacy.

\section{ABOUT THE AUTHOR}

Fabiola Varela-García is a professor of Spanish linguistics at the University of Wisconsin-Eau Claire, USA. ORCID: 0000-0003-0230-3606 